\title{
Geology, structure and age of the Nahuel Niyeu Formation in the Aguada Cecilio area, North Patagonian Massif, Argentina
}

\author{
Gerson A. Greco a, *, Pablo D. González a, Santiago N. González a , Ana M. Sato b, \\ Miguel A.S. Basei ${ }^{\text {c }}$, Colombo C.G. Tassinari ${ }^{\text {, }}$, Kei Sato ${ }^{\text {, }}$, Ricardo Varela ${ }^{\text {b }}$, \\ Eduardo J. Llambías b \\ ${ }^{a}$ Instituto de Investigación en Paleobiología y Geología, Universidad Nacional de Río Negro, Av. Julio A, Roca 1242, \\ $R 8332$ EXZ General Roca (Río Negro), Argentina \\ b Centro de Investigaciones Geológicas (UNLP-CONICET), Calle $1 N^{\circ}$ 644, B 1900 TAC La Plata (Buenos Aires), Argentina \\ ${ }^{\text {c } C e n t r o ~ d e ~ P e s q u i s a s ~ G e o c r o n o l o ́ g i c a s ~(I n s t i t u t o ~ d e ~ G e o c i e ̂ n c i a s, ~ U S P), ~ R u a ~ d o ~ L a g o ~ 562, ~ C E P ~ 05508-080 ~ S a ̃ o ~ P a u l o, ~ S P, ~ B r a z i l ~}$
}

\section{A R T I C L E I N F O}

\section{Article history:}

Received 18 December 2014

Accepted 26 April 2015

Available online 7 May 2015

\section{Keywords:}

SHRIMP U-Pb zircon age

Low-grade metamorphism

Cambrian-Ordovician

Late Permian

South Gondwana margin

Patagonia

\begin{abstract}
A B S T R A C T
The low-grade Nahuel Niyeu Formation in the Aguada Cecilio area $\left(40^{\circ} 50^{\prime} \mathrm{S}-65^{\circ} 53^{\prime} \mathrm{W}\right)$ shows ultramafic to felsic metaigneous rocks forming a sill swarm intercalated in the metasedimentary sequence and a polyphase deformation which permit an integrated study of the magmatic and tectonometamorphic evolution of this geological unit.

In this paper we present a geological characterization of the Nahuel Niyeu Formation in the Aguada Cecilio area combining mapping, structural and metamorphic analysis with a SHRIMP U-Pb age and geochemical data from the metaigneous rocks.

The metasedimentary sequence consists of alternating metagreywackes and phyllites, and minor metasandstones and granule metaconglomerates. The sills are pre-kinematic intrusions and yielded one SHRIMP U-Pb, zircon crystallization age of 513.6 +3.3 Ma. Their injection occurred after consolidation of the sedimentary sequence. A syn-sedimentary volcanic activity is interpreted by a metaandesite lava flow interlayered in the metasedimentary sequence. Sedimentary and igneous protoliths of the Nahuel Niyeu Formation would have been formed in a continental margin basin associated with active magmatic arc during the Cambrian Epoch 2. Two main low-grade tectonometamorphic events affected the Nahuel Niyeu Formation, one during the Cambrian Epoch 2-Early Ordovician and the other probably in the late Permian at $\sim 260$ Ma. Local late folds could belong to the final stages of the late Permian deformation or be even younger.

In a regional context, the Nahuel Niyeu and El Jagüelito formations and Mina Gonzalito Complex show a comparable Cambrian-Ordovician evolution related to the Terra Australis Orogen in the south Gondwana margin. This evolution is also coeval with the late and early stages of the Pampean and Famatinian orogenies of Central Argentina, respectively. The late Permian event recorded in the Nahuel Niyeu Formation in Aguada Cecilio area is identified by comparable structures affecting the Mina Gonzalito Complex and El Jagüelito Formation and resetting ages from granitoids. This event represents the Gondwanide Orogeny within the same Terra Australis Orogen.
\end{abstract}

() 2015 Elsevier Ltd. All rights reserved.

\footnotetext{
* Corresponding author. Tel.: +54 2984420886 .

E-mail addresses: gersongreco@gmail.com, ggreco@unrn.edu.ar (G.A. Greco), pdgonzalez@unrn.edu.ar (P.D. González), sgonzalez@unrn.edu.ar (S.N. González), sato@cig.museo.unlp.edu.ar (A.M. Sato), baseimas@usp.br (M.A.S. Basei), ccgtassi@ usp.br (C.C.G. Tassinari), keisato@usp.br (K. Sato), ricardovarela47@yahoo.com.ar (R. Varela), llambias@cig.museo.unlp.edu.ar (E.J. Llambías).
}

\section{Introduction}

Early Paleozoic basemenet rocks in the northeastern North Patagonian Massif (Fig. 1a-d) consist of a number of low-grade metamorphic rocks, such as Nahuel Niyeu (Caminos, 1983) and El Jagüelito (Ramos, 1975; Giacosa, 1987) formations, high-grade metamorphic rocks, such as Mina Gonzalito (Ramos, 1975; Giacosa, 1987) and Yaminué (Caminos, 1983) complexes, as well 


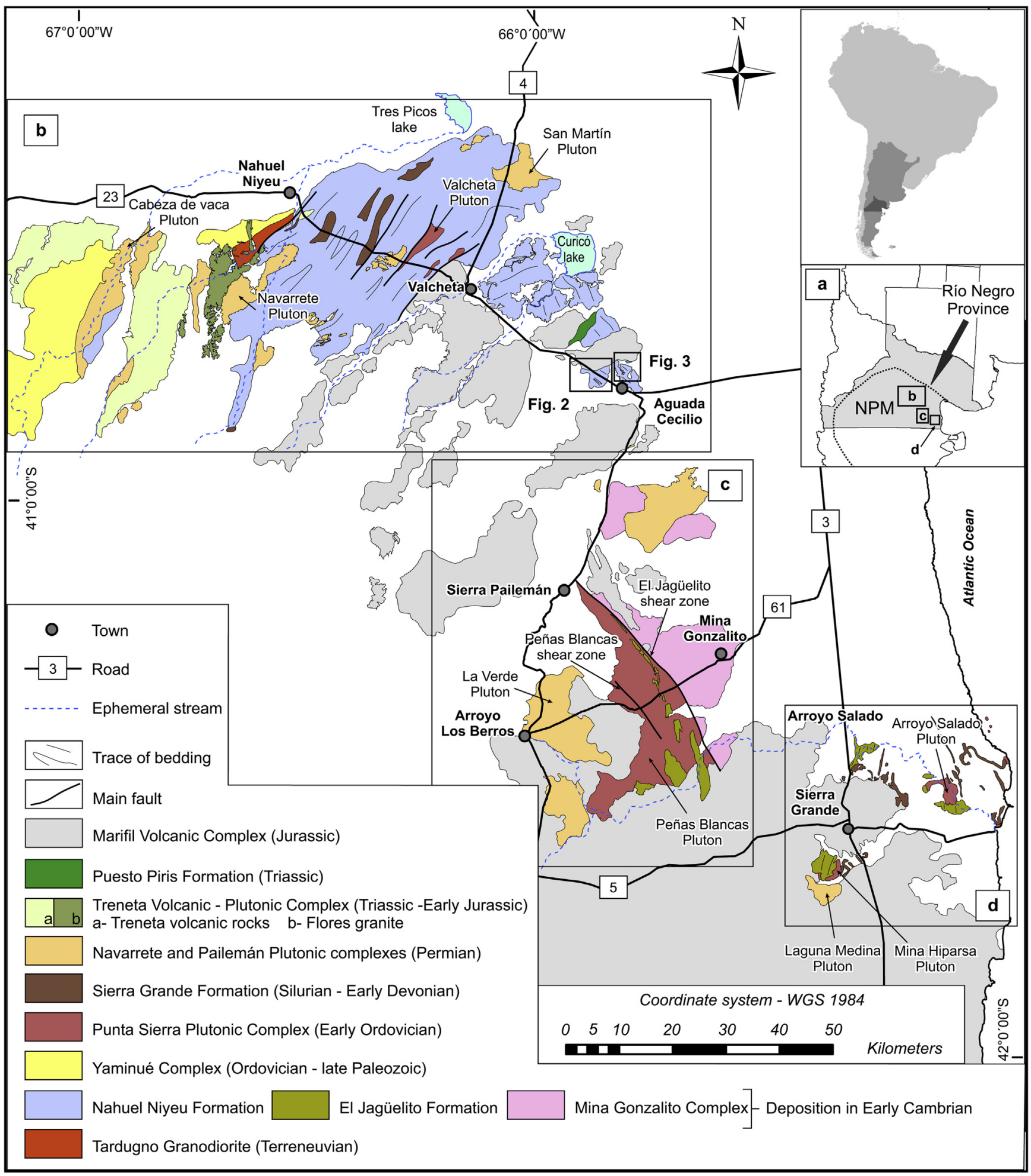

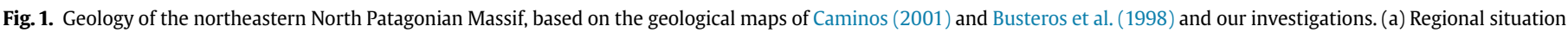

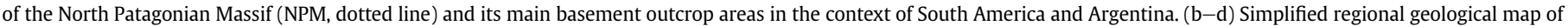
the Nahuel Niyeu-Aguada Cecilio (a), Mina Gonzalito-Sierra Pailemán (c), and Sierra Grande-Arroyo Salado (d) areas. Figure b shows location of Figs. 2 and 3.

as deformed and undeformed granitoid plutons, like Tardugno Granodiorite and Punta Sierra Plutonic Complex (Núñez, 1975; Busteros et al., 1998). Although with heterogeneous degree of information, the stratigraphic, paleontologic, structural, metamorphic and $\mathrm{U}-\mathrm{Pb}$ age constraints suggest mostly Cambrian deposition ages for the protoliths of both low and high-grade rocks, main Ordovician tectonometamorphic event, and Cambrian-Ordovician plutonism (Varela et al., 1998, 2008, 2011, 2014; Giacosa, 1994a,b, 1997, 1999, 2001; Chernicoff and Caminos, 1996a,b; González et al., 2002, 2008a,b,c, 2010a,b, 2011a,b,c, 2013a,b, 2014a,b; Giacosa, 2001; von Gosen, 2002, 2003; Pankhurst et al., 2006, 2014; Gozalvez, 2009a; López de Luchi 
et al., 2008; Naipauer et al., 2010; Rapalini et al., 2013; Chernicoff et al., 2013; Greco et al., 2013, 2014a,b; García et al., 2014a; among others). Part of these basement units is unconformably covered by fosiliferous Silurian-Devonian Sierrra Grande Formation (Harrington, 1962), and all the region is affected by late Paleozoic tectonism and magmatism.

The Cambrian-Ordovician interval involved in the basement evolution is equivalent to the transition between the Neoproterozoic to Middle Cambrian, Pampean orogenic cycle and the Late Cambrian to Devonian, Famatinian cycle (Aceñolaza and Toselli, 1976; Aceñolaza and Miller, 1982), both cycles well represented to the north of Patagonia. However, the posibility of Patagonia being allochthonous to this part of southwestern Gondwana previous to the late Paleozoic has been a matter of intense debate for decades (e.g., Ramos, 1984, 2008; Pankhurst et al., 2003, 2006; Gregori et al., 2008; López de Luchi et al., 2010; Rapalini et al., 2010). The Archeocyath fauna with affinity with the Australia-Antarctica paleobiographic province found in limestone blocks in northeastern Patagonia argues for an Antarctic connection and relation to the Ross orogeny of the Transantarctic Mountains (González et al., 2010a,b, 2011b,c; Naipauer et al., 2010; Ramos and Naipauer, 2014). However, other research lines suggest that the Pampean and Famatinian orogens from Norwestern Argentina and Sierras Pampeanas regions might stretch southward into the Patagonia (Varela et al., 1991; Dalla Salda et al., 1992; Pankhurst et al., 2003, 2006, 2014; Martínez Dopico et al., 2011; Rapalini et al., 2013).

The Nahuel Niyeu Formation is a mainly metasedimentary unit with wide outcrops between the localities of Nahuel Niyeu, Valcheta and Aguada Cecilio (Fig. 1b). In the areas of Nahuel Niyeu to Valcheta, it was mapped and structurally analyzed by Caminos (1983, 2001), Chernicoff and Caminos (1996a) and von Gosen (2003), with detrital zircon data published by Pankhurst et al. (2006) and Rapalini et al. (2013). Although smaller, the outcrops of Aguada Cecilio area show intercalated metamafic rocks and a polyphase deformation (Giacosa, 1994a,b, 1997, 1999; Martínez et al., 2001; Greco et al., 2013) which allows an integrated study of the magmatic and tectonometamorphic evolution of the Nahuel Niyeu Formation.

This study is focused on the mapping, structural and metamorphic analysis of the Nahuel Niyeu Formation in the surroundings of Aguada Cecilio $\left(40^{\circ} 50^{\prime} \mathrm{S}\right.$ and $\left.65^{\circ} 53^{\prime} \mathrm{W}\right)$, including description of the associated metaigneous rocks. Their results, together with a SHRIMP $\mathrm{U}-\mathrm{Pb}$ age and geochemical data from the metaigneous rocks, contribute to the characterization of the Cambrian-Ordovician tectonic setting of the region and the late Paleozoic tectonics.

The geologic time scale used in this contribution corresponds to the GSA Geologic Time Scale v4.0, which is mainly based on Gradstein et al. (2012). The approximate correspondence with the following traditional division of the Cambrian Period into Early (Terreneuvian and Epoch 2), Middle (Epoch 3) and Late (Furongian) is based on Babcock and Peng (2007) and Peng et al. (2012).

\section{Geologic setting}

Basement outcrops of northeastern North Patagonian Massif are depicted in Fig. 1b (Nahuel Niyeu to Aguada Cecilio area), Fig. 1c (Mina Gonzalito-Sierra Pailemán area) and Fig. 1d (Sierra GrandeArroyo Salado area).

The Nahuel Niyeu Formation between Nahuel Niyeu and Aguada Cecilio (Fig. 1b) is composed of alternating beds of phyllites, slates, quartz to quartzo-feldspathic metagreywackes, and minor intercalations of metasandstones, metaconglomerates and basic igneous rocks (Núñez, 1975; Núñez et al., 1975; Caminos, 1983, 2001; Giacosa, 1994a,b; Chernicoff and Caminos, 1996a; Greco et al., 2013, 2014a). Maximum deposition age is constrained by SHRIMP U-Pb detrital zircon ages of ca. 515 and $507 \mathrm{Ma}$ (Pankhurst et al., 2006; Rapalini et al., 2013). The metamorphic grade shows a general increase towards the east (Caminos and Llambías, 1984). Structural orientations of folded beds and associated foliation planes are variably oriented close to Nahuel Niyeu, where late Paleozoic thrust tectonics juxtaposes the Tardugno Granodiorite against the Nahuel Niyeu Formation (Caminos and Llambías, 1984; Chernicoff and Caminos, 1996b; von Gosen, 2003), while towards the east the main orientations are NE-SW. The Nahuel Niyeu Formation is intruded by two sets of granitoid plutons belonging to the Ordovician Punta Sierra and Permian Navarrete plutonic complexes (Caminos, 1983, 2001; Pankhurst et al., 2006; López de Luchi et al., 2008; Tohver et al., 2008; Gozalvez, 2009a,b; Rapalini et al., 2013), and minor dikes (Varela et al., 2001).

The medium to high-grade Yaminué Complex crops out to the southwest of Nahuel Niyeu (Fig. 1b) and consists of shallowly dipping stratified gneisses, schists and foliated tonalites to granodiorites and leucogranites, with minor amphibolites and marbles (Caminos, 2001; Caminos and Llambías, 1984; Chernicoff and Caminos, 1996b; von Gosen, 2003). Despite initially considered as Precambrian ( $\mathrm{Rb}-\mathrm{Sr}$ whole rock data, Caminos et al., 1994), more recent conventional and SHRIMP $\mathrm{U}-\mathrm{Pb}$ studies have disclosed magmatic crystallization ages of deformed granitoids in the Terreneuvian (Tardugno Granodiorite), Ordovician and Permian-Carboniferous intervals (Basei et al., 2002; Chernicoff et al., 2013; Rapalini et al., 2013; Pankhurst et al., 2014). This variety of magmatic ages, added to a Carboniferous maximum deposition age of a paragneiss (detrital zircons with SHRIMP U-Pb ages, Chernicoff et al., 2013), makes difficult the understanding of the whole sedimentary, tectonometamorphic and magmatic evolution of the Yaminué Complex, particularly because the geologic and structural relationships between the dated units are not clear.

The Mina Gonzalito Complex (Fig. 1c) is composed of paragneisses, schists, marbles, amphibolites, orthogneisses and syntectonic granites. SHRIMP and LA-ICPMS U-Pb dating of detrital zircons (Pankhurst et al., 2006; Greco et al., 2014b) show maximum depositional ages of 540-535 Ma and $515 \mathrm{Ma}$, comparable to those of the Nahuel Niyeu Formation, with additional metamorphic rims dated at $472 \mathrm{Ma}$. This is consistent with a SHRIMP U-Pb zircon crystallization age of $492 \pm 6$ Ma of a granodiorite orthogneiss (Varela et al., 2011), affected together with the country rocks by penetrative NNW-SSE to NW-SE trending foliations (Giacosa, 1997; González et al., 2008a). The brittle-ductile El Jagüelito shear zone (Fig. 1c; Ramos, 1975; Ramos and Cortés, 1984; Giacosa, 1993, 1994a,b, 1997) juxtaposes the Mina Gonzalito Complex against the Peñas Blancas Pluton (Fig. 1c; Giacosa, 1997). The latter pluton has recently been assigned to the Punta Sierra Plutonic Complex, on the basis of an Ordovician SHRIMP U-Pb zircon age (García et al., 2014a). This shear zone and the Peñas Blancas shear zone affecting the Peñas Blancas Pluton represent the Permian tectonism in this area (Fig. 1c, Giacosa, 2001; von Gosen, 2002), while other plutons belonging to the Pailemán Plutonic Complex (Giacosa, 1993, 1997; Grecco et al., 1994; García et al., 2014b) represent the Permian magmatism.

The El Jagüelito Formation is a turbiditic sequence lithologically comparable to the Nahuel Niyeu Formation (Caminos and Llambías, 1984; Giacosa, 1987; von Gosen, 2003) and consisting of slates, phyllites, metagreywackes, metasandstones, with minor mafic layers, metaconglomerates, intercalations of metatuffs, metaignimbrites, metaandedesite and metarhyolite lava flows, and metarhyolitic dikes and domes (de Alba, 1964; Giacosa and Paredes, 2001; González et al., 2002, 2008b, 2011a,b, 2013a, 2014a,b). It is well exposed in the area of Sierra Grande-Arroyo Salado (Fig. 1d), and poorly exposed in the west of Mina Gonzalito (Fig. 1c). Detrital 
zircon ages with youngest peaks between 535 and 523 Ma (Pankhurst et al., 2006; Naipauer et al., 2010) are consistent with the finding of trace fossils (González et al., 2002) and Archeocyathan limestone blocks in a metaconglomerate (González et al., 2011b). Pervasive NNW-SSE to NNE-SSW foliation, dipping with high angle to the $\mathrm{W}$, accompanies tight and overturned folds (Giacosa and Paredes, 2001; von Gosen, 2002; González et al., 2008b, 2011a,b, 2014a,b). Several granitoid plutons belonging to the Punta Sierra Plutonic Complex intrude the El Jagüelito Formation after the first tectonometamorphic event. Their conventional and SHRIMP U-Pb zircon ages are between 476 and $462 \mathrm{Ma}$ (Varela et al., 1998, 2008; Pankhurst et al., 2006; González et al., 2008c; García et al., 2014a). Permian magmatism of the Pailemán Plutonic Complex also affects the southern Sierra Grande area (Varela et al., 2008).

Silurian-Devonian sandstones and quartzites of the Sierra Grande Formation containing fossils of the Malvinokaffric fauna cover the El Jagüelito Formation and eroded Ordovician granitoids in the area of Sierra Grande-Arroyo Salado (Fig. 1d). They are affected by late Paleozoic folding and thrusting with main NNW-SSE orientations (Harrington, 1962; de Alba, 1964; Zanettini, 1981; Cortés, 1981; Huber-Grünberg, 1990; Busteros et al., 1998; von Gosen, 2002). In the area of Nahuel Niyeu to Valcheta, nonfosiliferous but comparable sedimentary sequences unconformably covering the Nahuel Niyeu Formation and also affected by late Paleozoic tectonism are assigned to the Sierra Grande Formation (Fig. 1b; Sesana, 1968; Methol and Sesana, 1972; Núñez et al., 1975; Caminos, 1983, 2001; Chernicoff and Caminos, 1996a; von Gosen, 2003).

After the late Paleozoic tectonic and magmatic events, Triassic to Early Jurassic Treneta Volcanic-Plutonic Complex develops in the Nahuel Niyeu area (Fig. 1b; Caminos, 1983; Pankhurst et al., 1993; López de Luchi et al., 2008), and then all the region is dominated by a widespread Jurassic rhyolitic magmatism of the Marifil Volcanic Complex (Fig. 1b-d; Malvicini and Llambías, 1974; Cortés, 1981; Pankhurst and Rapela, 1995; Pankhurst et al., 1998; Márquez et al., 2011), including basal volcaniclastic strata (Fig. 1b; Puesto Piris Formation, Núñez, 1975) and andesitic-trachyandesitic volcanic beds and dikes (González et al., 2014a,b).

\section{Lithology of the Nahuel Niyeu Formation in the surroundings of Aguada Cecilio}

In the Aguada Cecilio area, the Nahuel Niyeu Formation is mainly composed of alternating metagreywackes and phyllites, and minor metasandstones and granule metaconglomerates, which define the relict bedding $\left(\mathrm{S}_{0}\right)$ (Figs. 2 and $3 \mathrm{a}, \mathrm{b}$ and $4 \mathrm{a}$ ). In addition, Giacosa (1994a,b, 1997, 1999) and Greco et al. (2013, 2014a) mentioned intercalations of metagabbro/diorites forming part of the same sequence.

The igneous rocks are widely distributed in the area. They are subvolcanic sills which intruded with sharp contacts parallel to bedding $\left(\mathrm{S}_{0}\right)$ of the still undeformed and non-metamorphosed clastic sedimentary sequence (Figs. 2 and 3a,b). Additionally, an effusive lava flow also concordant with $\mathrm{S}_{0}$-planes is found in close association (Fig. 2). The sills display a local thermal metamorphism with centimetric to decimetric hornfels on both contact surfaces of the country rock into which they are intruded (Fig. 4b). The lava flow exhibits a contact thermal overprint only along its base.

The sills are simple or composite and are arranged in a WNW-ESE trending swarm within an area of $\sim 10 \mathrm{~km}$ by $\sim 7 \mathrm{~km}$ (Figs. 2 and 3). Individually, they are $1-150 \mathrm{~m}$ thick and $0.2-3 \mathrm{~km}$ long. Simple sills consist of gabbro/diorite or peridotite with variations in their grain size. The former composition predominates over the latter. We mapped only two composite sills that comprise two different sets of compositions. The border zone with mafic and ultramafic rocks is interpreted as their base. One composite sill presents a 1-4 m thick base of peridotite with a thicker gabbro/ diorite section toward the roof (Fig. 2). The other composite body is a larger sill that includes a $20-30 \mathrm{~m}$ thick base of gabbro/diorite and a main body of granodiorite with thin lenses of granite as magmatic differentiation products (Figs. 2 and 4c). In all cases, contacts among facies are transitional without chilled margins.

The central zone of the thicker sills preserves relics of igneous minerals and textures (Fig. 4c and d). Igneous minerals are partially or even pseudomorphically replaced by mineral association of regional metamorphism (see Section 5). Metaperidotites and metagabbro/diorites preserve relics of cumulate and medium to fine-grained equigranular textures, respectively. Metagranodiorites and metagranites still reveal patches of typical magmatic equigranular textures (Fig. 4c). The thinner gabbroic sills also preserve relics of subvolcanic diabase textures in the central zone.

Mafic and ultramafic igneous rocks from the border zones of the thicker composite and simple sills and those of the thinner simple ones are transformed into greenschists with a penetrative schistose structure (Fig. 4d and e). Similarly, felsic rocks of the mafic to felsic composite sill are transformed into schistose metagranitoids close to its border zone.

Up to now, one bed of effusive lava was found intercalated with metagreywackes and phyllites (Fig. 2). It is a 1.5-2 m-thick tabular layer, composed of stretched and boudinaged segments, folded together with the sedimentary sequence. The lava is composed of a porphyritic andesite which preserves relics of its primary igneous minerals and texture. It also preserves vesicles along the top side of the flow, and a mixture between a pillow lava structure and peperite at the base (Fig. 4f).

\section{Structure of the Nahuel Niyeu Formation}

The sills together with their respective hornfelses share the same folded structure and metamorphism as those of their host rocks (Greco et al., 2013, 2014a). Therefore, they were intruded before the onset of deformation and metamorphism.

The structures are described here in chronological order and correspond to five deformation stages that have been recognized in the Nahuel Niyeu Formation. $\mathrm{D}_{1}$ and $\mathrm{D}_{2}$ structures are associated with the penetrative metamorphic foliations that characterize these rocks. After that, microgranodiorite dikes cut $D_{1}-D_{2}$ structures. Subsequent to the intrusion of these dikes, a new deformation stage $D_{3}$ affected them for the first time and refolded the $D_{1}-D_{2}$ fabric. $D_{4}$ and $D_{5}$ structures represent the final stages of the deformational history.

\section{1. $D_{1}-D_{2}$ structures}

Two sets of superposed, coaxial WNW-ESE trending $F_{1}$ and $F_{2}$ folds forming Type III interference patterns of Ramsay (1962) characterize the $D_{1}$ and $D_{2}$ deformation structures (Figs. 2, 3a,b and $5 a, b) . F_{1}$ and $F_{2}$ folds are isoclinal, similar and their axes plunge towards the WNW. A high angle NNE-dipping $S_{1}$ and $S_{2}$ axial plane cleavage/schistosity is associated with both folds (Fig. $5 a$ and b). $S_{1}$ and $S_{2}$ foliations are subparallel in the limbs of $F_{1}$ and $F_{2}$ folds (Fig. $6 a$ and $b$ ), but in the hinge zone of the $F_{2}$ folds, $S_{2}$ constitutes a crenulation cleavage/schistosity (Fig. 6c). In this zone, it is common to see the $S_{1}$ foliation partially or completely transposed by the $S_{2}$ foliation. The intersection between $S_{1}$ and $S_{2}$ cleavage/schistosity defines the WNW-trending $\mathrm{L}_{2}$ lineation that is parallel to $\mathrm{B}_{2}$ and $\mathrm{B}_{1}$ axes (Fig. $6 \mathrm{~d}$ ). The structures described above are penetrative in the metasedimentary rocks, greenschists and schistose metagranitoids contrasting to the central zone of the sills that conserve their relict igneous texture. 


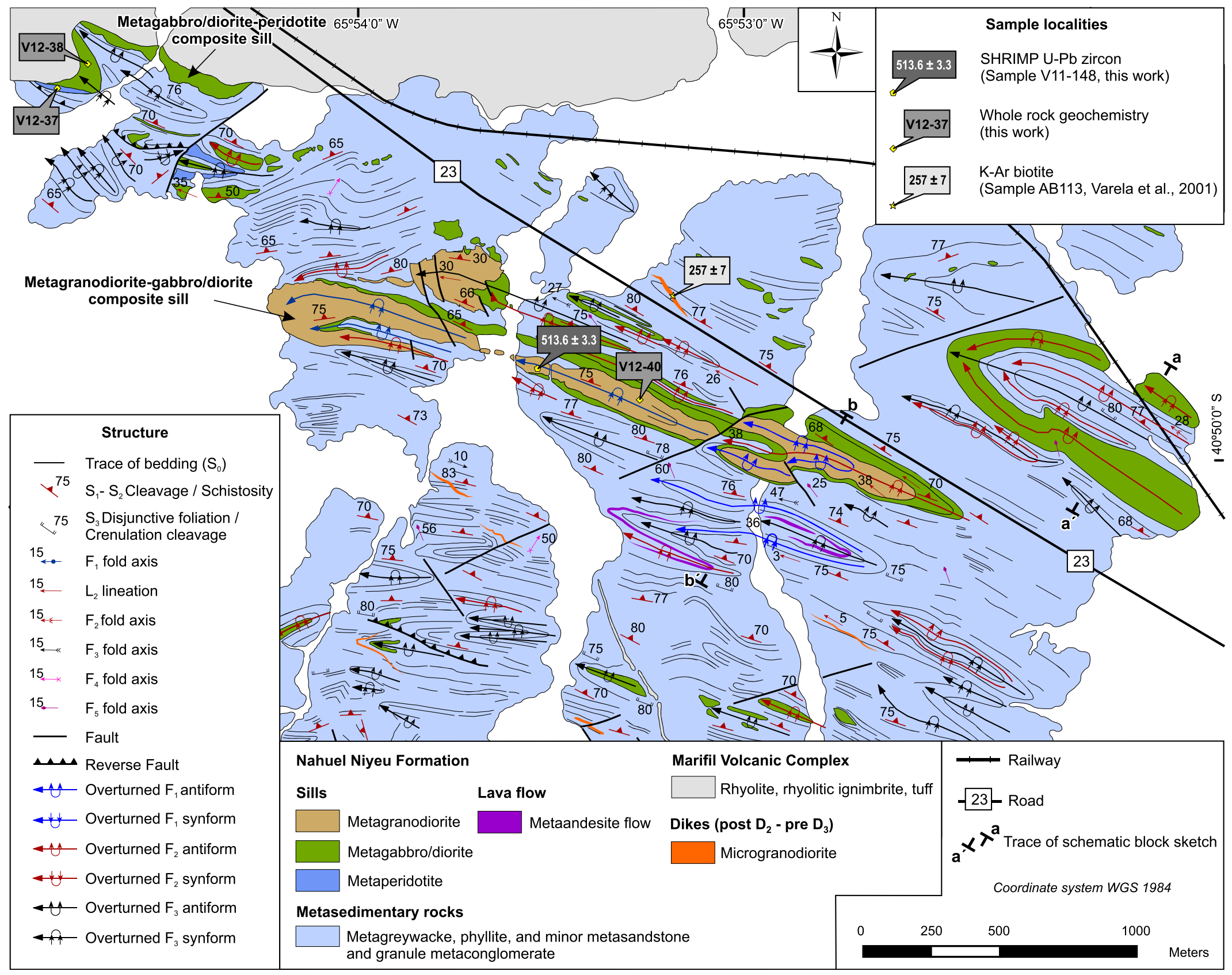

Fig. 2. Geological map of the area west of Aguada Cecilio town with samples localities and the trace of the schematic block sketch a- $\mathrm{a}^{\prime}-\mathrm{b}-\mathrm{b}^{\prime}$ in Fig. $5 \mathrm{a}$. Map based on our field work. 


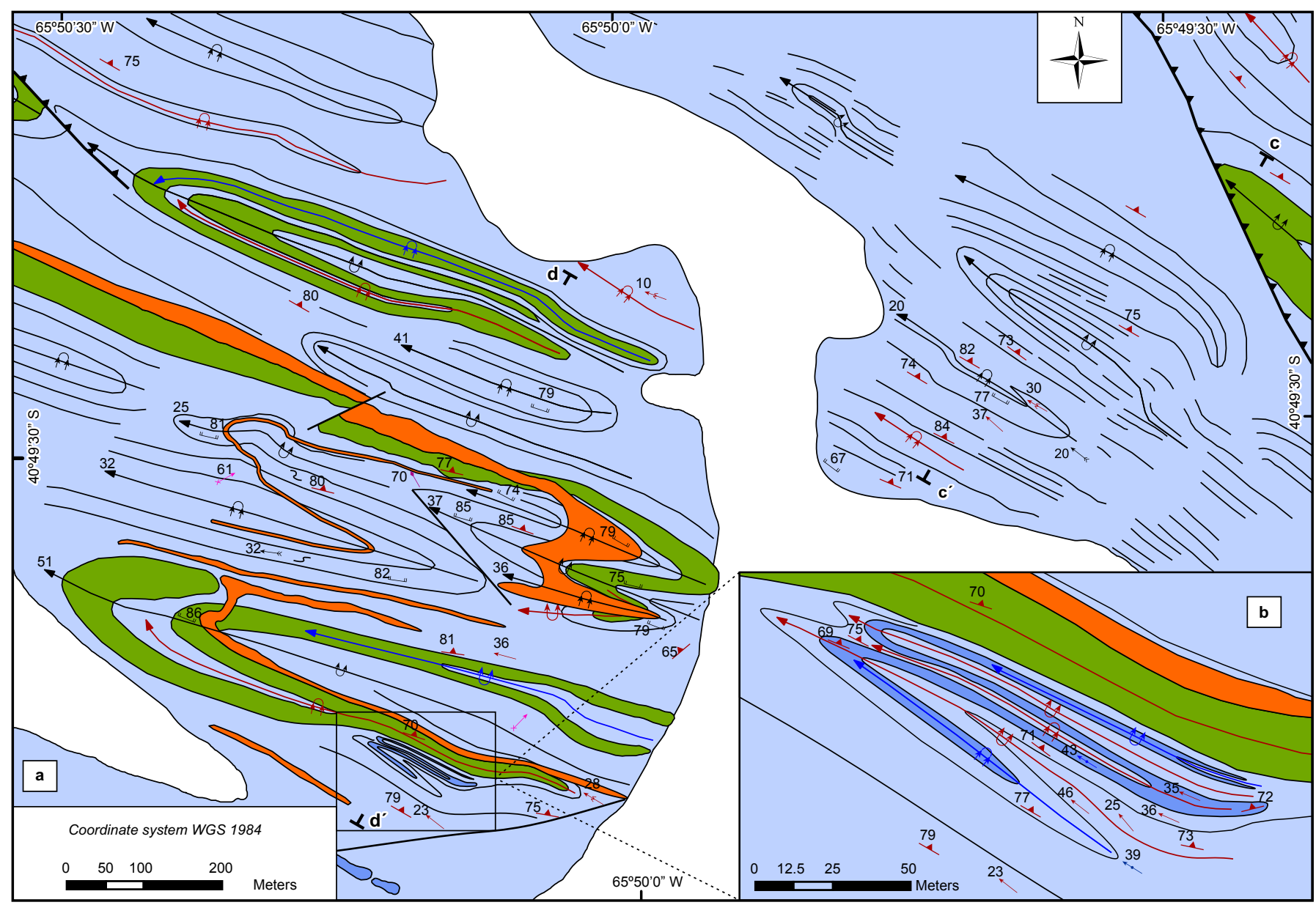

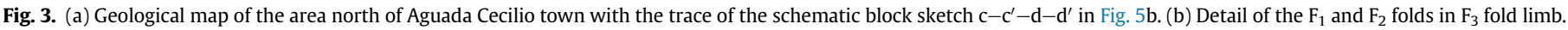
The legend of the maps is shown in Fig. 2. Map based on our field work.

\subsection{Post $D_{2}-$ pre $D_{3}$ dikes}

WNW-ESE trending, biotite-bearing microgranodiorite dikes cut the $S_{1}-S_{2}$ foliation planes in the limbs and hinge zones of the $F_{1}$ and $F_{2}$ folds at low and high angles, respectively (Figs. 5b and 7a). They contain numerous enclaves of the low grade metamorphic country rock (Fig. 7b), and locally produce a thermal metamorphism that overprints textures of the previous regional metamorphism.

\section{3. $D_{3}$ structures}

WNW-ESE trending $\mathrm{F}_{3}$ folds (first folding in microgranodiorite dikes) and high-angle reverse faults dipping to the NNE are the most conspicuous structures in the Nahuel Niyeu Formation (Figs. 2 and 3 ). $\mathrm{F}_{3}$ folds are tight to isoclinal and their axial planes dip $75^{\circ}-85^{\circ}$ to the NNE, resulting in overturned folds with vergence to the SSW; similarly the reverse faults indicate a tectonic transport to the SSW (Fig. 5a and b). The $S_{3}$ axial plane crenulation cleavage and disjunctive schistosity $\left(\mathrm{S}_{1}\right.$ schistosity in microgranodiorite dikes) characterize the hinge zone of the $F_{3}$ folds (Fig. 6e). Pencil structures occur in the $F_{3}$ hinge zones where the $S_{3}$ foliation intersects the $S_{1}-S_{2}$ foliation (Fig. $6 f$ ). $B_{3}$ fold axes are subparallel to those of $F_{1}$ and $F_{2}$ folds (Fig. 5a,b). Therefore, $F_{3}$ folding results in the second Type III interference pattern (Ramsay, 1962) that we observe in the low-grade basement rocks (Figs. 2, 3 and $5 \mathrm{a}, \mathrm{b})$.

\section{4. $D_{4}$ and $D_{5}$ structures}

Two sets of kink folds affect all the structures and rocks described above. On the basis of their temporal relationship, we describe the kink folds as $F_{4}$ and $F_{5}$. The NE-SW trending $F_{4}$ and the NNW-SSE trending $F_{5}$ folds are local and have centimetric to decametric sizes. These folds locally alter the strike and dip of the previous planar and linear structures (Figs. 2 and 3).

\section{Microfabrics and metamorphism}

\subsection{Nahuel Niyeu Formation}

\subsubsection{Metasedimentary rocks}

Metasedimentary rocks preserve relict detrital grains of quartz, plagioclase, alkali feldspar, polycrystalline quartz and lithics of phyllites and igneous rocks. The recrystallized matrix that surrounds the detritus contains metamorphic minerals forming foliation planes (Fig. $8 \mathrm{a}$ and $\mathrm{b}$ ). $\mathrm{S}_{1}$ cleavage/schistosity contains the first metamorphic association composed of chlorite + biotite + muscovite + epidote + quartz \pm tourmaline \pm calcite, which is characteristic of greenschist facies metamorphism (biotite zone). $F_{2}$ microfolds are associated with an $\mathrm{S}_{2}$ axial plane crenulation cleavage/schistosity formed by rigid grain rotation, recrystallization and neoformation of $S_{1}$ minerals. In this way, both $S_{1}$ and $S_{2}$ display the same metamorphic mineral association (Fig. $8 \mathrm{c}$ and d). The $S_{3}$ crenulation cleavage is defined by fine chlorite, sericite and oxides 

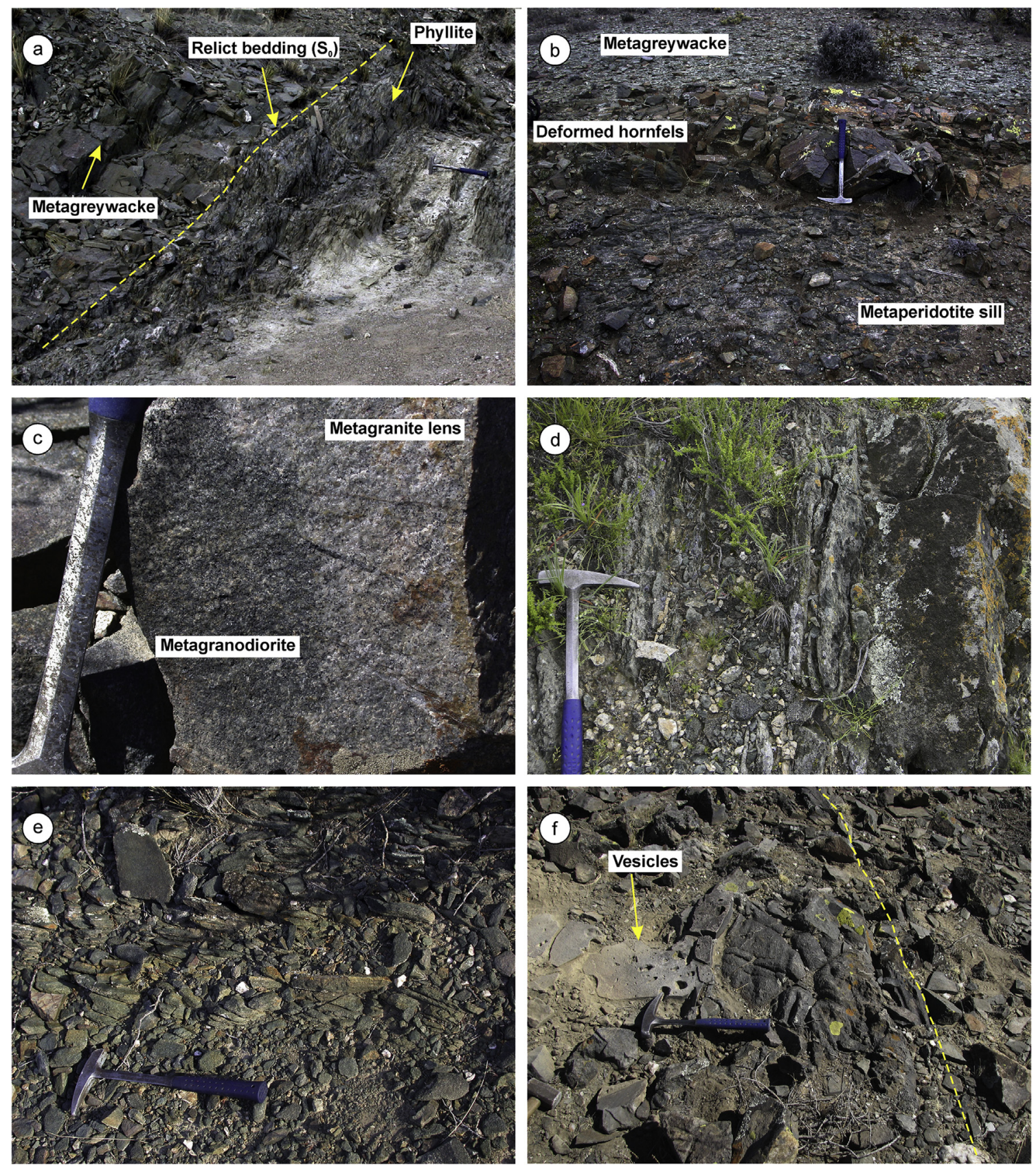

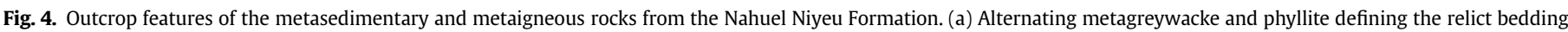

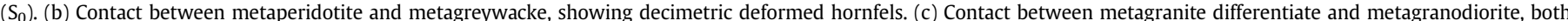

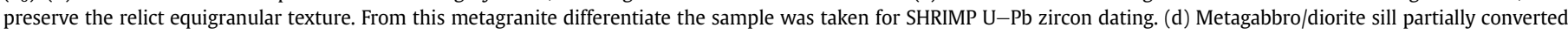

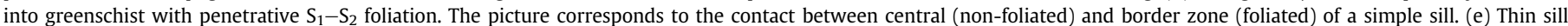

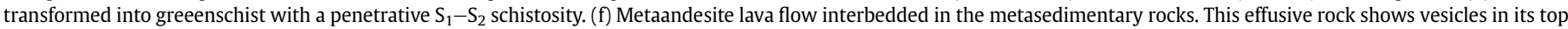
side. The dashed line indicates the concordant contact of the lava flow with bedding $\left(\mathrm{S}_{0}\right)$.

along dissolution surfaces. This mineral association is distinctive of greenschist facies metamorphism (chlorite zone). $F_{3}$ microfolds present rotation and reorientation of $\mathrm{S}_{1}-\mathrm{S}_{2}$ minerals along $\mathrm{S}_{3}$ foliation planes.

\subsubsection{Greenschists and metagabbros/diorites}

Greenschists present a metamorphic mineral association of tremolite-actinolite + chlorite + epidote + albite + calcite + titanite \pm quartz (Fig. 9a) defining the planar $S_{1}$ fabric and replacing pseudomorphically the relict igneous minerals such as amphibole, plagioclase, opaque mineral and biotite. This mineral association is typical of greenschist facies in mafic protoliths (Bucher and Grapes, 2011, p. 363 and references therein). In these rocks and at right angle to the $L_{2}$ lineation and $F_{2}$ microfolds, the $S_{1}$ foliation is partially transposed by the $S_{2}$ schistosity. The latter is defined by a greenish brown biotite that partially replaces the chlorite, tremolite-actinolite and relict igneous amphibole (Fig. 9a). The greenish brown biotite is characteristic of the greenschist facies at around $\sim 400{ }^{\circ} \mathrm{C}$ (Bucher and Grapes, 2011, p. 364 and references therein). Although this biotite can be present from greenschist to upper 


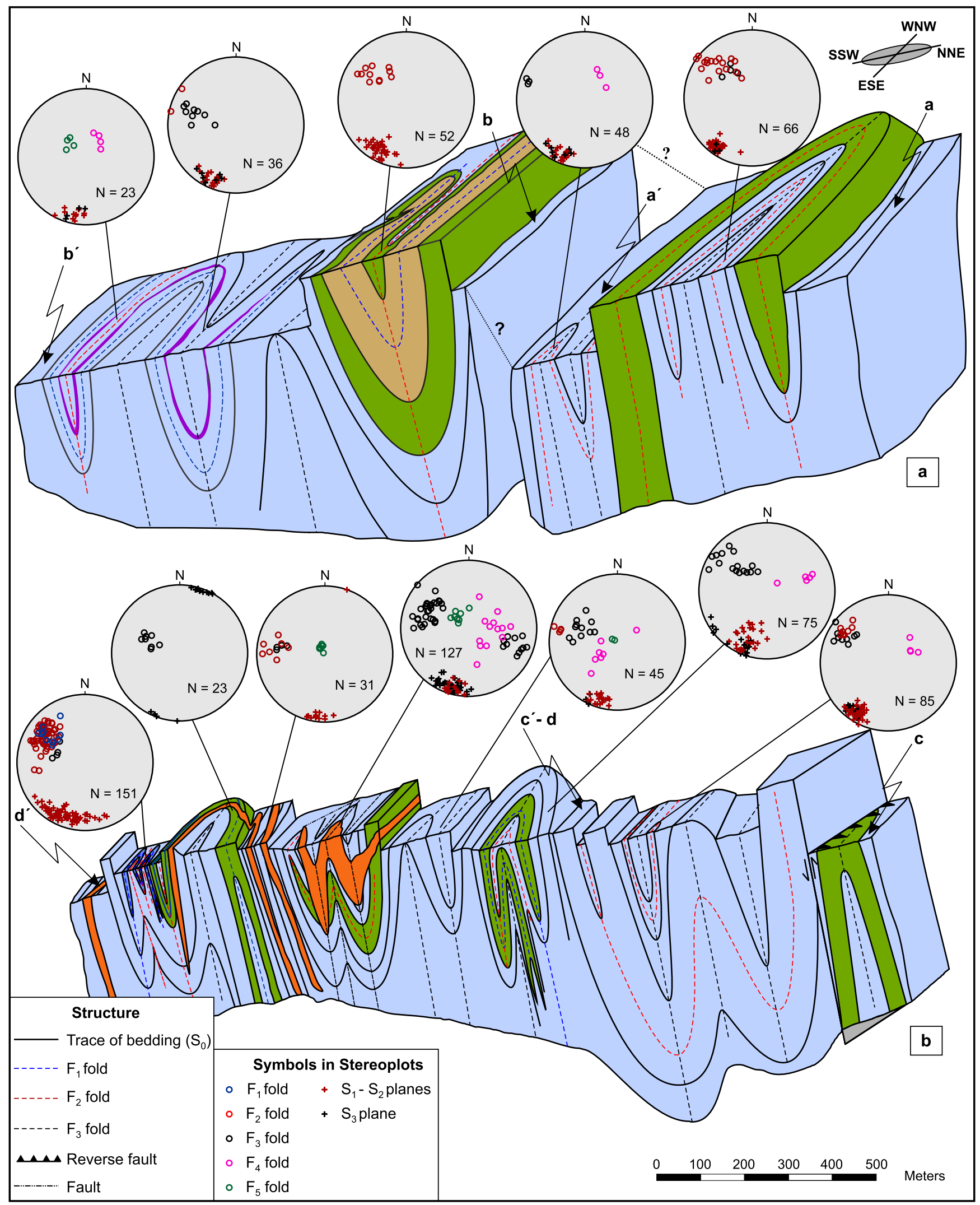

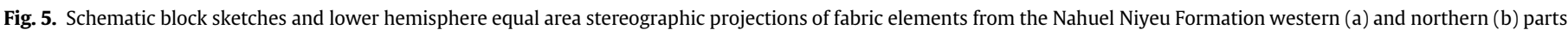

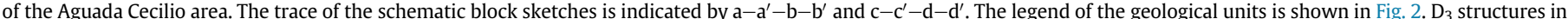
the Nahuel Niyeu Formation are equivalents to $D_{1}$ structures in the microgranodiorite dikes. For the locations of block sketches see Figs. 2 and $3 a$. 

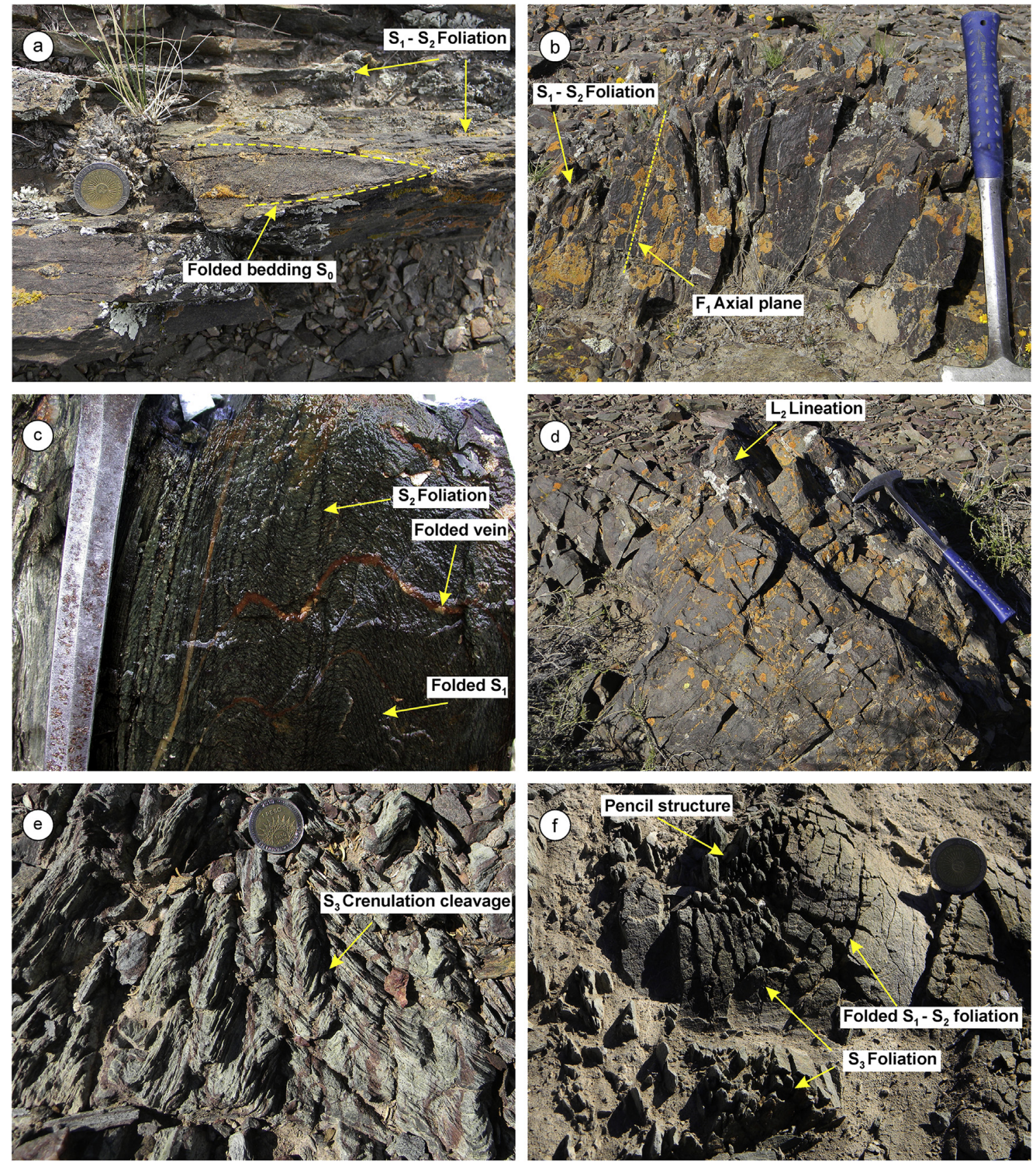

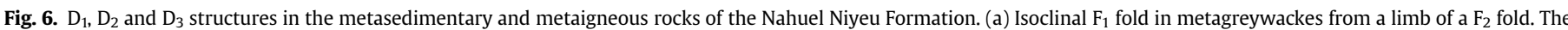

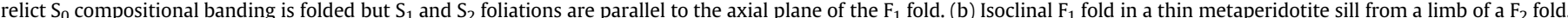

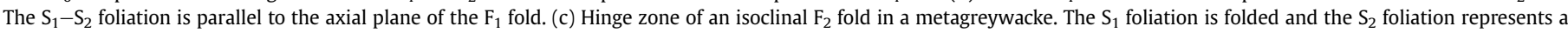

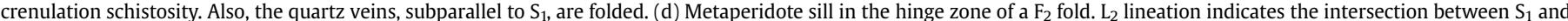

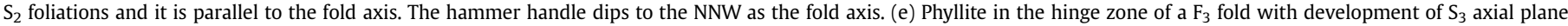
crenulation cleavage. (f) Hinge zone of a $F_{3}$ fold in greenschist with pencil structures. The $S_{1}-S_{2}$ foliation is folded and crosscuted by the $S_{3}$ foliation.

amphibolite facies (Bucher and Grapes, 2011, p. 350 and references therein), we consider that the most reasonable metamorphic grade reached during the development of the $S_{2}$ metamorphic foliation was greenschist facies on the basis of the absence of metamorphic hornblende.

Metagabbro/diorite sills that preserve their relict igneous minerals and textures typically contain euhedral plagioclase and interstitial minerals such as amphibole, sagenitic biotite, opaque mineral, and quartz with alkali feldspar constituting micrographic textures (Fig. 9b). An early replacement of the igneous mineralogy is observed, where decussate chlorite replaces mafic minerals, clinozoisite the plagioclase cores, and pumpellyite the amphibole, while prehnite "cysts" appear in the biotite. This early replacement and the relict igneous mineralogy are partially or even pseudomorphically replaced by the main metamorphic mineral association of tremolite-actinolite + chlorite + epidote + albite + titanite + calcite + quartz (Fig. 9b), which is consistent with greenschist facies conditions (Bucher and Grapes, 2011, p. 363 and references therein). The observed metamorphic reaction clinozoisite + fine decussate chlorite $\rightarrow$ tremolite-actinolite + albite that is also typical of prograde metamorphism of basic rocks at greenschist facies (Bucher and Grapes, 2011, p. 357). Greenish 

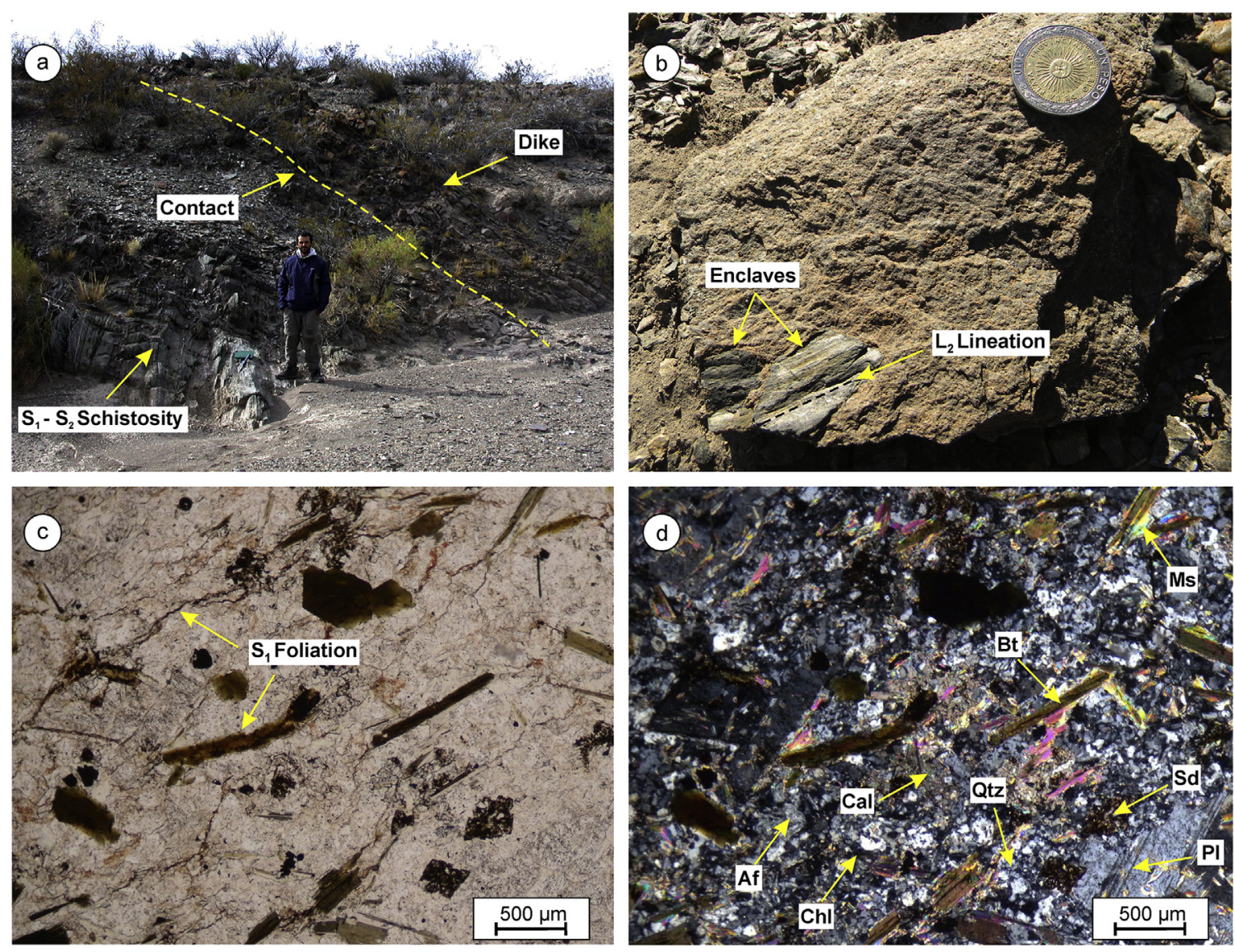

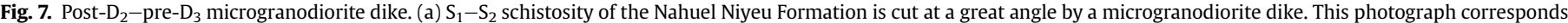

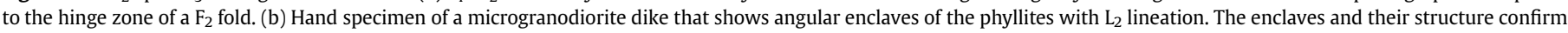

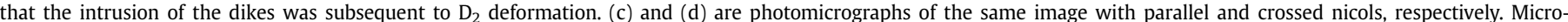

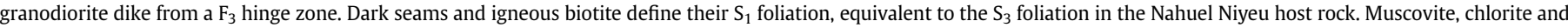

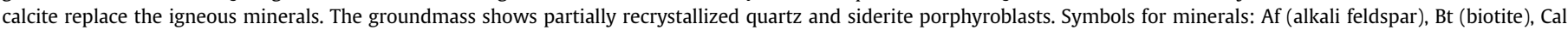
(calcite), Chl (chlorite), Ms (muscovite), Pl (plagioclase), Qtz (quartz), Sd (siderite).

brown biotite replaces chlorite, tremolite-actinolite and igneous amphibole (Fig. 9b).

\subsubsection{Metaperidotites}

Cumulus olivine and intercumulus of pyroxene, brown amphibole, opaque mineral and minor sagenitic biotite compose the metaperidotite cumulates (Fig. 9c). Cumulates exhibit an early serpentinization that affects olivine and pyroxene. Pseudomorphic cummingtonite-grunerite replacing brown amphibole and serpentine, and blue chlorite replacing sagenitic biotite (Fig. 9c) represent the main metamorphic mineralogy in cumulates. This mineral association (cummingtonite-grunerite + blue chlorite) also suggests conditions of a greenschist facies metamorphism (Evans and Ghiorso, 1995 and references therein), as does the association talc + bowlingite + fine green chlorite + muscovite + tremolite-actinolite, which fill microfractures and replace the previous mineral associations (Fig. 9c).

\subsubsection{Metagranitoids}

Schistose metagranitoids show a penetrative $S_{1}-S_{2}$ schistosity recorded by alternating micaceous and quartzo-feldspathic domains (Fig. 9d). The micaceous domains contain a metamorphic mineral association of biotite + epidote + actinolite + muscovite + calcite, which is coherent with greenschist facies conditions (Fig. 9d). Actinolite pseudomorphically substitutes and grows at the expense of biotite. The quartzo-feldspathic domains show a typical fabric of dynamic recrystallization with relict igneous minerals such as quartz, plagioclase, and alkali feldspar. The relict igneous quartz grains have undulose extinction, deformation bands and subgrain boundaries. The relict feldspars exhibit fragmentation, deformation twins, bending, undulose extinction, and grain boundary recrystallization (Fig. 9d).

Metagranodiorites include patches with equigranular magmatic textures, and contain quartz, plagioclase, alkali feldspar with micrographic textures and relict mafic mineral (amphibole?) as essential minerals, and minor apatite, allanite and zircon. Metagranitic magmatic differentiates within metagranodiorites display granular textures. They are composed of quartz and microcline in micrographic textural arrangements, plagioclase, and relics of a mafic mineral (amphibole?) (Fig. 9e). Apatite and zircon are also common accessory minerals. Although metagranodiorites/granites partially preserve their igneous textures, quartz shows intracrystalline microstructures such as undulose extinction, deformation bands, and subgrain boundaries. It was also affected by dynamic recrystallization (Fig. 9e). The mafic mineral is pseudomorphically replaced by biotite + epidote and the feldspars are partially replaced by albite + calcite + epidote. These replacement minerals represent the main metamorphic mineral association, which is equivalent to that observed in the schistose metagranitoids. 

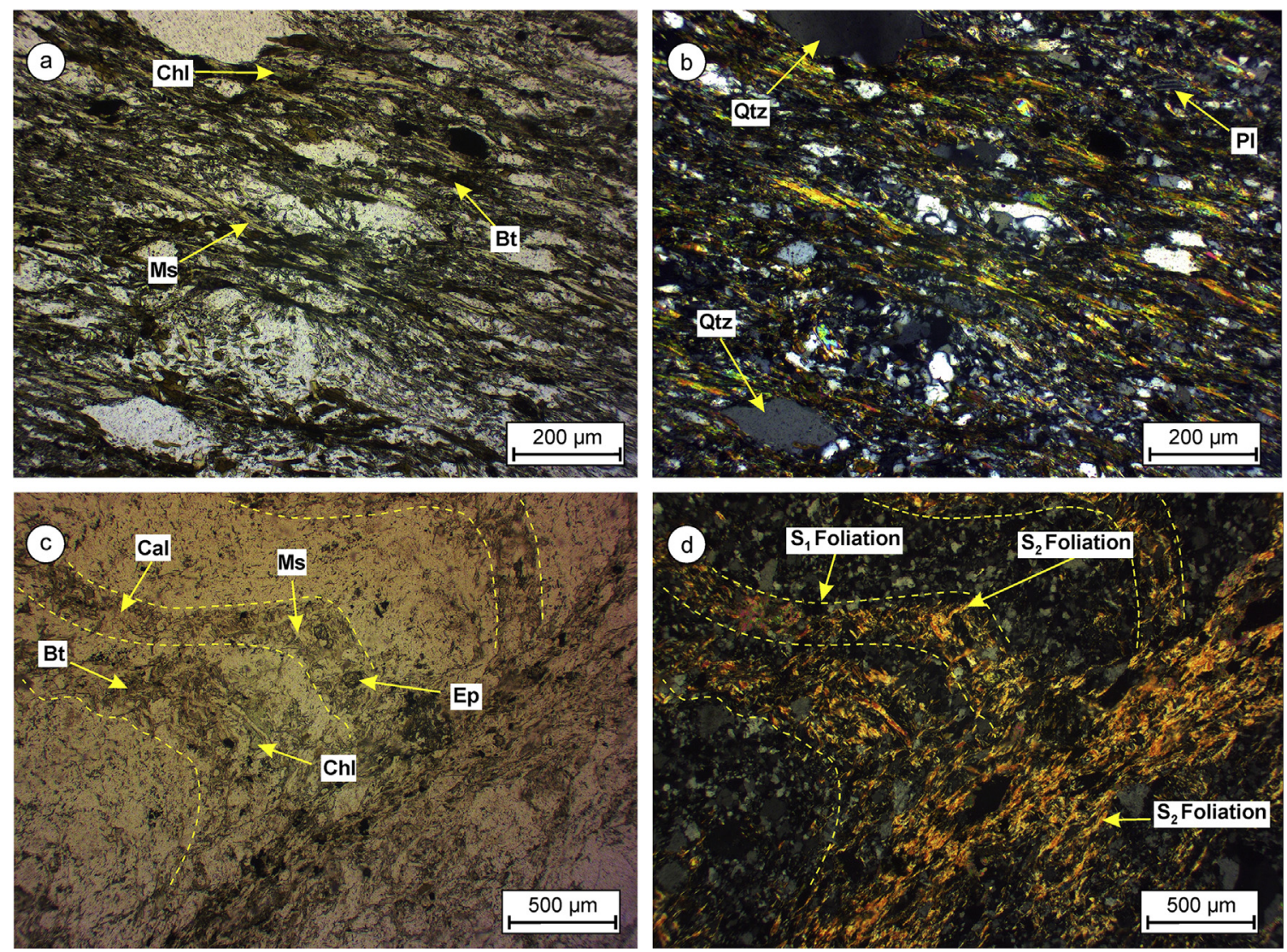

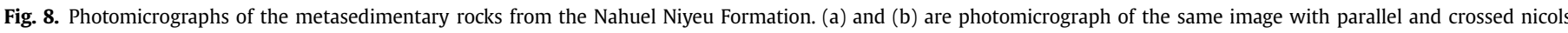

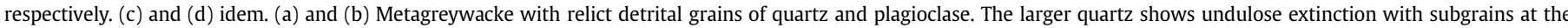

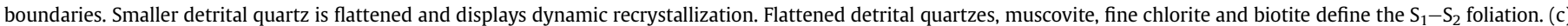

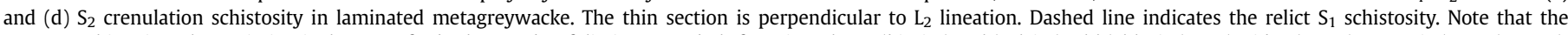

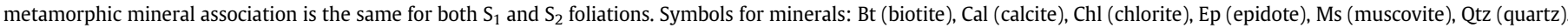

\subsubsection{Metaandesite}

The metaandesite lava flow has a relict porphyritic texture composed of amphibole and plagioclase phenocrysts in a partially recrystallized groundmass (Fig. 9f). The magmatic flow parallel to the top and base of the lava is recorded by the long axis orientation of amphibole phenocrysts. The amphibole shows pseudomorphic replacement by the metamorphic association of chlorite + epidote + calcite + greenish brown biotite \pm actinolite; the greenish brown biotite appears replacing the chlorite (Fig. 9f). The plagioclase has deformation twins and in its core displays the same mineral association that replaces the amphibole. The groundmass preserves some relict igneous crystals but is mainly composed of the metamorphic association epidote + albite + calcite + chlorite + greenish brown biotite + quartz + microperthitic feldspar (Fig. 9f). Metamorphic associations in this rock also are equivalent to those of the greenschists and metagabbros/diorite and, therefore, characteristic of greenschist facies conditions (Bucher and Grapes, 2011, p. 363 and references therein).

\subsection{Microgranodiorite dikes}

Microgranodiorite dikes cutting the $S_{1}-S_{2}$ foliations contain plagioclase and biotite phenocrysts, the latter defining an igneous foliation. Plagioclase, quartz, and alkali feldspar with quartz in micrographic textural arrangements constitute the microgranular groundmass. In $\mathrm{F}_{3}$ hinge zones the dikes present their first axial plane schistosity (equivalent to $S_{3}$ planes in the Nahuel Niyeu Formation). This foliation is defined by dark seams, originated by accumulation of opaque grains along dissolution surfaces, and reoriented igneous biotite (Fig. 7c and d). Muscovite and calcite replace the plagioclase phenocryst. Kinked biotite phenocrysts show pseudomorphic replacement by muscovite. In the groundmass, calcite, muscovite and chlorite substitute the feldspars while undulose quartz is partially recrystallized. The groundmass contains additional siderite porphyroblasts (Fig. $7 \mathrm{c}$ and $\mathrm{d}$ ). The replacement minerals represent a similar metamorphic condition to that associated with the $\mathrm{D}_{3}$ structures of the Nahuel Niyeu Formation.

\section{SHRIMP U-Pb zircon analytical procedure and result}

One sample of a metaigneous rock interbedded in the metasedimentary sequence of the Nahuel Niyeu Formation was selected for zircon study and SHRIMP U-Pb dating. After a failed attempt to collect zircons from the metagranodiorite facies of the metagranodiorite-gabbro/diorite composite sill (Fig. 2), we collected $20 \mathrm{~kg}$ of a metagranite differentiate within the same facies (sample V11-148, Figs. 2 and 4c). Standard jaw-crushing, sieving and separation into $75,108,150$ and $212 \mu \mathrm{m}$ size fractions, as well as heavy minerals concentration by elutriation processes and magnetic susceptibility techniques were performed at the laboratories of the Centro de Investigaciones Geológicas (Universidad Nacional de La Plata-CONICET). Zircon grains were hand-picked in alcohol under a binocular microscope to obtain fractions of similar shape, color and size. About two hundred zircons were selected from the least magnetic fractions. 

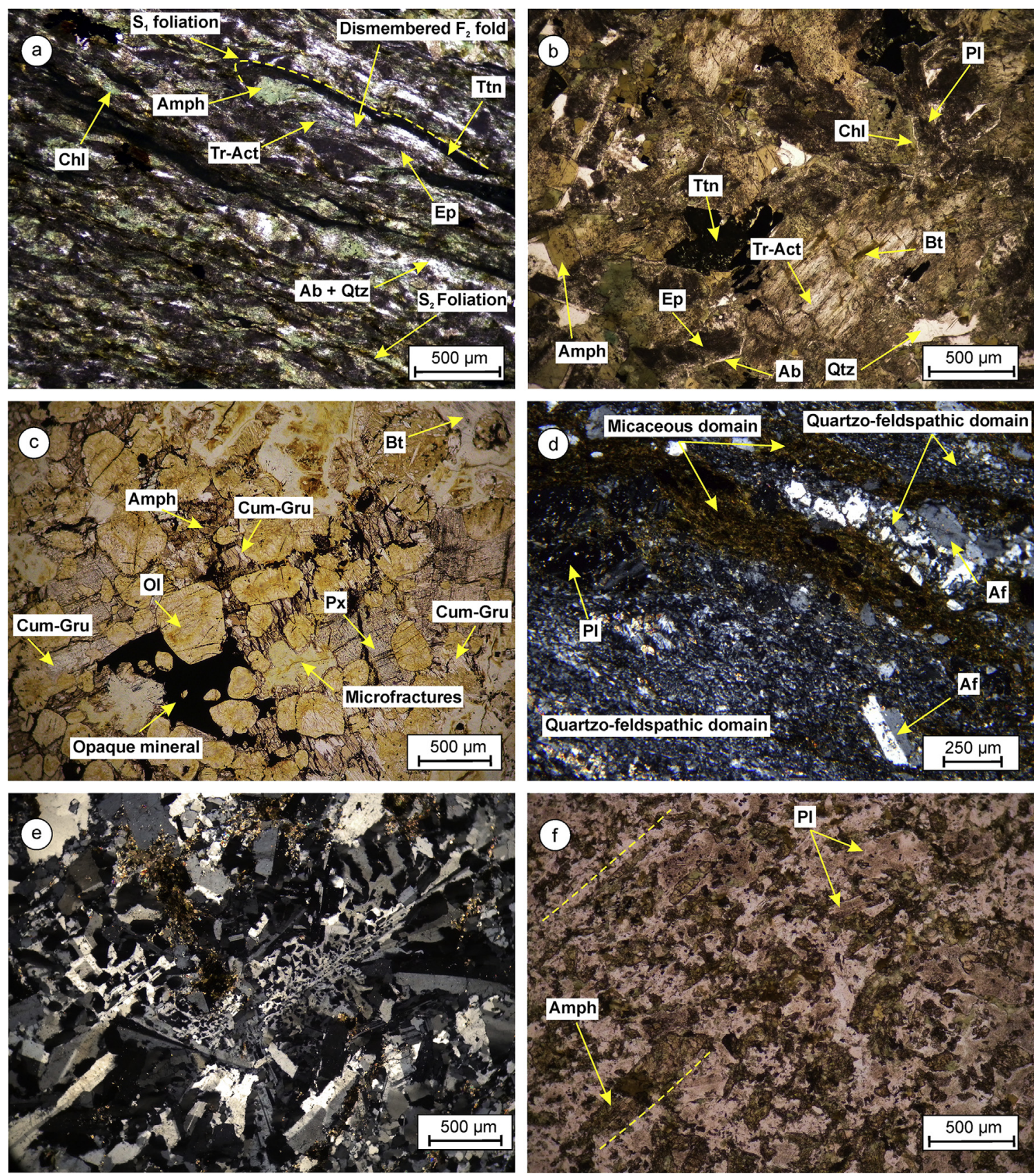

Fig. 9. Photomicrographs of the metaigneous rocks from the Nahuel Niyeu Formation. Transmitted light, parallel nicols in a, b, c and f. Crossed nicols in d and e. (a) Thin section perpendicular to $\mathrm{L}_{2}$ lineation of a greenschist Tremolite-actinolite, chlorite, epidote, albite, titanite and quartz are arranged according to $S_{1}$ foliation, which is partially transposed by $S_{2}$ foliation. Greenish brown biotite defines the $S_{2}$ foliation. Dismembered $F_{2}$ fold show a relict amphibole partially replaced by chlorite, in its hinge zone. (b) Metagabbro/diorite with relict igneous minerals and texture. Pseudomorphic replacements of: amphibole by tremolite-actinolite, chlorite and greenish brown biotite; euhedral plagioclase by epidote, chlorite and albite; opaque mineral by titanite and chlorite. Quartz is a relict interstitial mineral. (c) Metaperidotite cumulate. Olivine, pyroxene, brown amphibole, biotite and opaque mineral are the relict igneous minerals. Olivine and pyroxene are pervasively serpentinized. Cummingtonite-grunerite replaces the serpentine and the brown amphibole. Fine green chlorite and bowlingite fill the microfractures and replace the previous mineral associations. (d) Schistose metagranodiorite with micaceous and quartzo-feldspathic domains which define the $S_{1}-S_{2}$ schistosity. Plagioclase and alkali feldspar are relict igneous minerals. (e) Metagranite differentiate with relict igneous minerals and micrographic texture. Quartz grains in the lower right quadrant show undulose extinction, deformation bands and subgrain boundaries. (f) Metaandesite lava flow with relict porphyritic texture. Chlorite + epidote + calcite + greenish brown biotite + actinolite substitute the phenocrysts of amphibole and plagioclase, and the minerals of the groundmass. Dashed lines indicate the orientation of the phenocrysts by magmatic flow. Symbols for minerals: Ab (albite), Amph (amphibole), Af (alkali feldspar), Bt (biotite), Chl (chlorite), Cum-Gru (cummingtonite-grunerite), Ep (epidote), Ol (olivine), Pl (plagioclase), Px (pyroxene), Qtz (quartz), Tr-Act (tremolite-actinolite), Ttn (titanite).

SHRIMP U-Pb ages were obtained using the SHRIMP IIe instrument of the Centro de Pesquisas Geocronológicas (CPGeo), Instituto de Geociências, Universidade de São Paulo (USP), Brasil. Prior to SHRIMP analyses, the selected zircon grains were mounted in epoxy resin and plugged together with standard zircons (TEMORA-2 reference zircon with ${ }^{206} \mathrm{~Pb} /{ }^{238} \mathrm{U}$ age $=416.78 \pm$
$0.33 \mathrm{Ma}$, Black et al., 2004). The mount was polished and documented using optical (reflected and transmitted light) and scanning electron microscopy (Secondary Electrons and Cathodoluminescence), in order to select the sites for $\mathrm{U}-\mathrm{Pb}$ analysis on the basis of internal structure and fracturing degree of the grains (McLaren et al., 1994). After extensive cleaning, the mount was 
coated with ultra-pure gold ( $\sim 3 \mathrm{~nm}$ thick) and inserted into the SHRIMP for analysis. The analytical method follows those described by Compston et al. (1984) and Williams (1998). Correction for common ${ }^{206} \mathrm{~Pb}$ is made using the measured ${ }^{204} \mathrm{~Pb}$ according to Stacey and Kramers (1975). The data were filtered to remove analysis with $>3 \%{ }^{206} \mathrm{~Pb}$ of common origin before age calculations. Data from the SHRIMP analyses are represented in a Concordia diagram produced with ISOPLOT/Ex (Ludwig, 2008). All analytical errors are presented at $1 \sigma$ level. The SHRIMP $\mathrm{U}-\mathrm{Pb}$ results are summarized in the Table A.1 of the Appendix A.

The zircons from the metagranite are prismatic, amber color or colorless and transparent and their lengths range from 120 to $75 \mu \mathrm{m}$, with an aspect ratio of 3.1-1.3 (Table A.1). In cathodoluminescence (CL) images, crystals show low luminescence, oscillatory and sector zoning typical of magmatic zircon, or homogeneous internal texture (Fig. 10a). We discarded six out of seventeen analyzed zircons by high ${ }^{206} \mathrm{~Pb}$ of common origin (Table A.1). One cluster of five concordant zircons yielded a ${ }^{206} \mathrm{~Pb} /{ }^{238} \mathrm{U}$ Concordia age of $513.6 \pm 3.3 \mathrm{Ma}(\mathrm{MSWD}=0.84$, Fig. 10b). One zircon from this cluster (spot 9.1) displays $5.62 \%$ common ${ }^{206} \mathrm{~Pb}$, but it is concordant and its age is coherent with the age of the cluster. From these reasons we did not discard this particular zircon. The five concordant zircons have magmatic features such as sector and oscillatory zoning, well-defined faces, and high Th/U values (Fig. 10a,b and Table A.1). Therefore, we interpret the Concordia age as the magmatic crystallization age of the metagranite. Since this granite is a magmatic differentiate from the granodiorite (Fig. 4c), the concordia age can be assigned to the crystallization age of the whole sill (Fig. 2). The remaining zircon grains have younger ${ }^{206} \mathrm{~Pb} /{ }^{238} \mathrm{U}$ ages, between $\mathrm{ca}$. $487 \mathrm{Ma}$ and $\mathrm{ca}$. $396 \mathrm{Ma}$ which could be interpreted as $\mathrm{Pb}$ loss probably due to regional metamorphism and deformation (Table A.1). A preliminary report of these ages was early presented by Greco et al. (2014a).

\section{Whole-rock geochemistry}

Three whole-rock geochemical compositions from the sills were determined. Samples V12-37 and V12-38 correspond to metaperidotite and metagabbro/diorite, respectively, and both of them belong to the same sill. Sample V12-40 corresponds to a metagranodiorite. Sample localities are shown in Fig. 2. Whole rock powders, prepared at Centro de Investigaciones Geológicas, La Plata, were sent to ACME Analytical Laboratories S.A., Canada (http://acmelab.com/) for major, trace and REE element analysis using alkaline fusion with lithium borate and being diluted with acid digestion to perform ICP-ES and ICP-MS methods. Results of the geochemical analyses are summarized in the Table A.2 of the Appendix A. Major element data were recalculated to $100 \%$ on anhydrous basis before using them in classification diagrams (Fig. 11a and b).

The samples are classified as peridotite-gabbro (V12-37), subalkalic gabbro (V12-38) and granodiorite (V12-40) with 42.4-64.7 wt.\% $\mathrm{SiO}_{2}$ (Fig. 11a). All samples plot in the field of the subalkaline series and belong to the tholeiitic series (Irvine and Baragar, 1971) (Fig. 11a and b). The MORB-normalized spider diagrams show a relative enrichment in large-ion lithophile elements (LILE) and a sharp increase in $\mathrm{Rb} / \mathrm{Yb}$ values in the more silicic compositions; also these diagrams exhibit negative anomalies in HFSE (Nb, P and Ti) especially in the basic and intermediate compositions (Fig. 11c). These characteristics are typical of subduction related magmas (Gill, 2010, p. 190). Moreover, as the negative Nb anomaly is distinctive of the continental crust, it could indicate a crustal involvement in magma processes (Rollinson, 1993, p. 148). Chondrite-normalized Rare Earth Elements (REE) plots (Sun and McDonough, 1989) show flat patterns for the samples V12-37 and V12-38, whereas the sample V12-40 displays a light REE (LREE) enrichment with a negative Eu anomaly (Fig. 11d).

\section{Discussion}

\subsection{Age and tectonic setting of the Nahuel Niyeu Formation}

A syn-sedimentary volcanic activity can be interpreted to have occurred during the deposition of the Nahuel Niyeu sequence, on the basis of the metaandesite lava flow interbedded in the metasedimentary rocks (Fig. 12). As the lava shows pillow and peperite structures, this volcanism may have happened in a subaqueous environment.
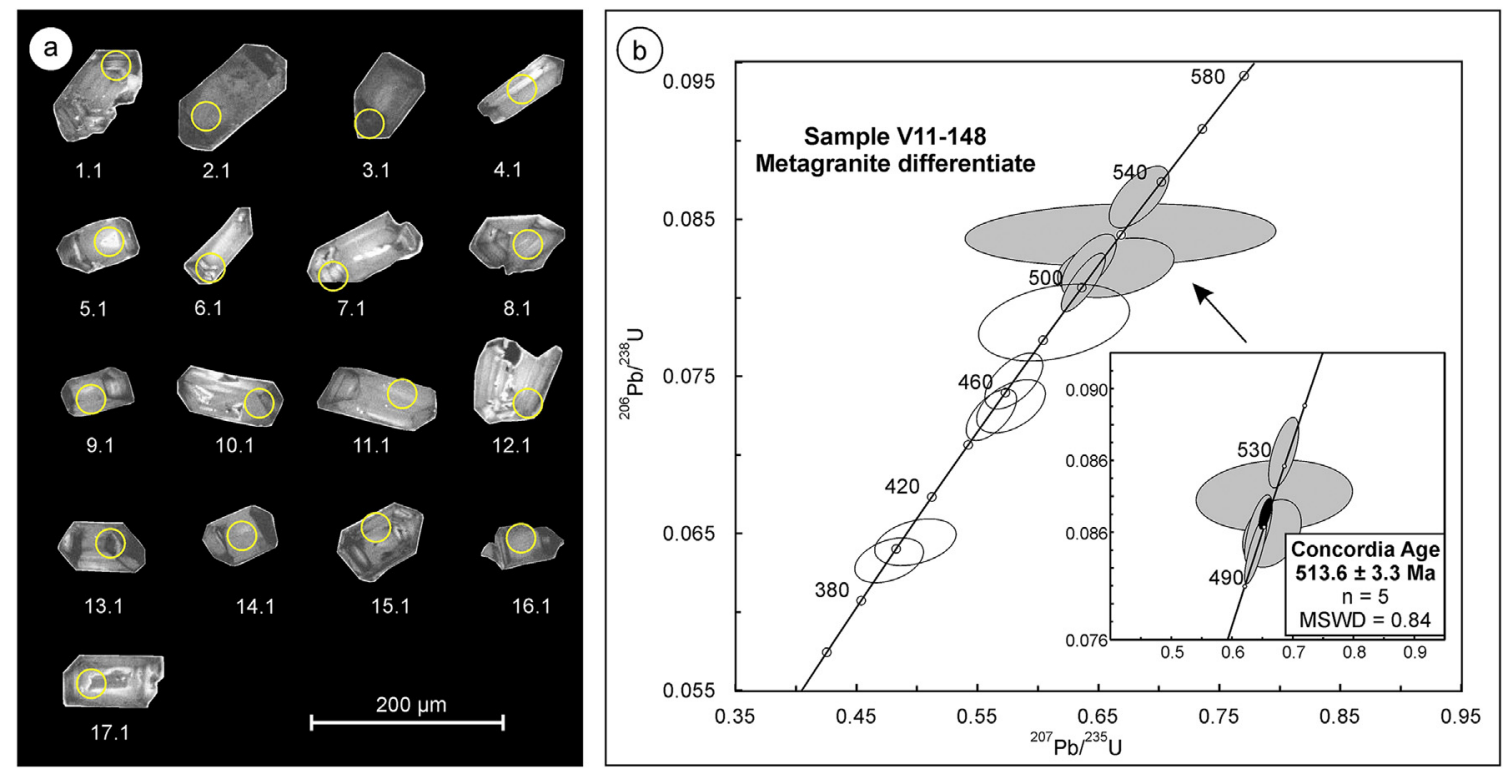

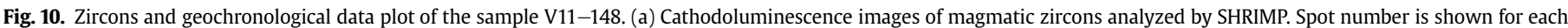

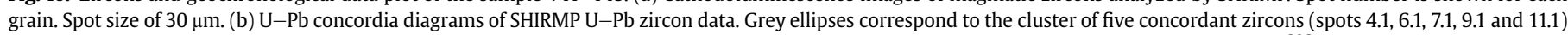
that yield the Concordia age. This age is given at $1 \sigma$ confidence level. Spots 1.1, 2.1, 3.1, 10.1, 13.1 and 17.1 were not plotted because of their high ${ }^{206} \mathrm{~Pb}$ of common origin. 

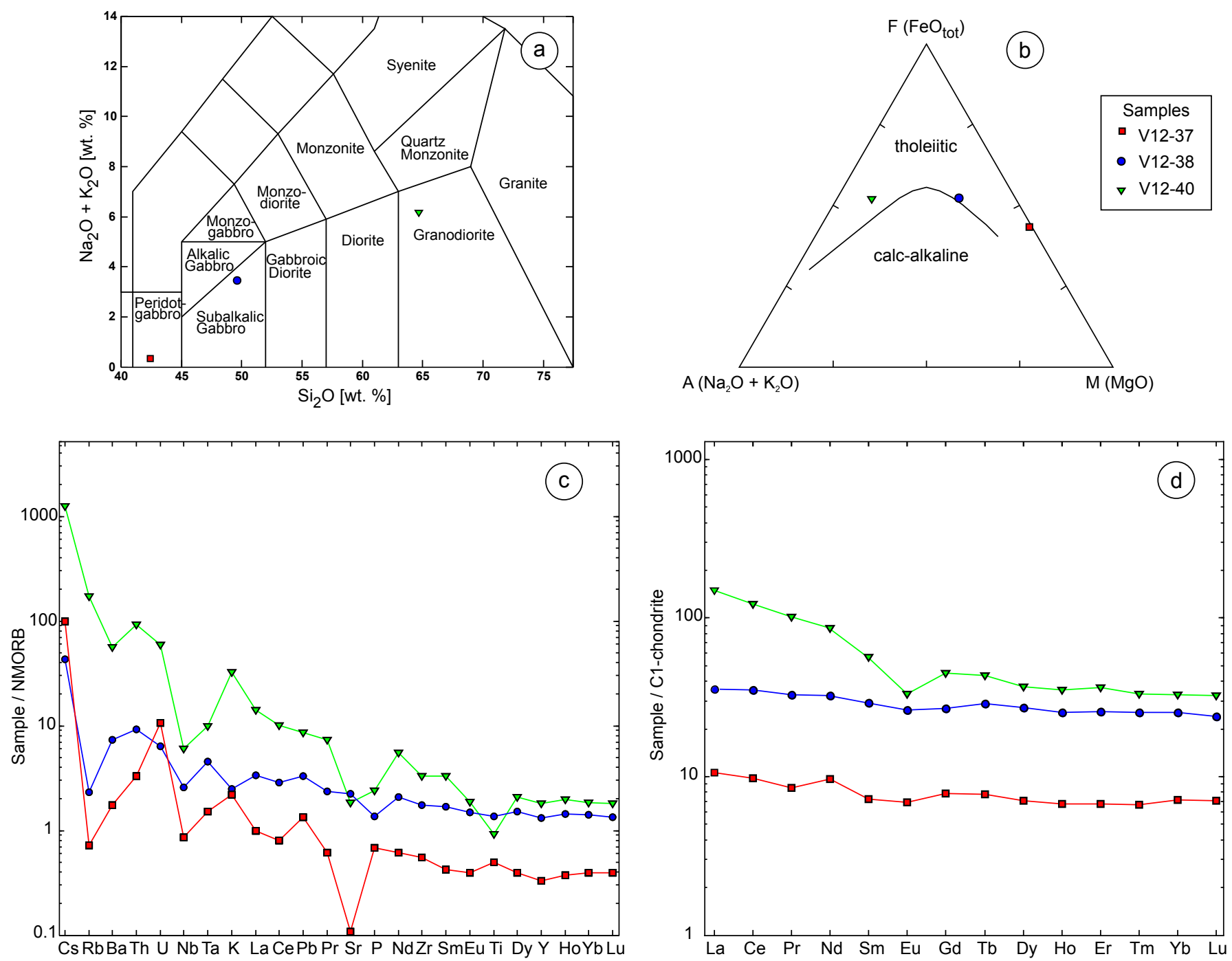

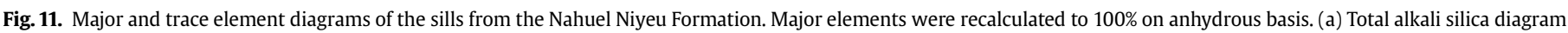
for plutonic rocks (after Middlemost, 1994). (b) AFM plot. (c) MORB-normalized spider diagrams. (d) Chondrite-normalized Rare Earth Elements (REE) plots.

The sharp contacts displayed by the sills, parallel to the relict $S_{0}$ sedimentary bedding of the Nahuel Niyeu Formation (Figs. 2 and 3a,b), suggest that their injection occurred after consolidation of the clastic sequence, but previous to the onset of deformation and metamorphism, as shown by the fact that the sills share all the deformation structures and associated metamorphism with the metasedimentary country rock (Fig. 12). At this respect, the sills might even be genetically connected with the andesitic lava flow.

Our mapping has shown that metagabbro/diorite simple sills dominate over the other igneous bodies (Figs. 2 and 3), and only two composite sills are present in the studied outcrops. However, future mapping in the surrounding areas might reveal additional and comparable sills. As the contacts between the igneous facies are transitional without chilled margin, the metaperidotite cumulate at the base of the composite metagabbro/diorite-peridotite sill (Fig. 2) could be the product of gravitational or flow segregation from the gabbroic magma. Besides, the transitional contact between the basal metagabbro/diorite and the metagranodiorite of the large composite sill (Fig. 2) suggests a common magmatic differentiation process for these igneous facies. Likewise, the thin lenses of metagranite as magmatic differentiates in the metagranodiorite suggest a similar process (Fig. 4c). From the above, a spatial, temporal and genetic relationship between the gabbro/ diorite, peridotite, granodiorite and granite igneous facies is likely. Therefore, we can assign the age of $513.6 \pm 3.3 \mathrm{Ma}$ obtained in this study to the crystallization age of the entire sill swarm (Fig. 12).

Maximum depositional ages between $515 \mathrm{Ma}$ and $507 \mathrm{Ma}$ in the south of Nahuel Niyeu town (Pankhurst et al., 2006; Rapalini et al., 2013) are similar to our unpublished detrital zircon data from the host rocks of the sills in Aguada Cecilio that yield maximum depositional ages of 516.6-515 Ma (Fig. 12). The proximity between the maximum depositional ages and the crystallization age of the sills suggests deposition was followed by rapid consolidation of the sedimentary beds. This was accompanied by active continental margin magmatism. This situation is supported by the geochemical characteristics of the sills, which indicate subduction related tholeiitic magmatism and involvement of continental crust. Moreover, prominent younger peaks from detrital zircon distributions of the Nahuel Niyeu Formation (Pankhurst et al., 2006; Rapalini et al., 2013; Greco et al., unpublished data) suggest erosion from a nearby active magmatic arc (Pankhurst et al., 2006; Cawood et al., 2012). Furthermore, petrographical and geochemical studies performed by Cagnoni et al. (1993), Giacosa (1997) and Caminos (2001) in metasedimentary rocks south of the Nahuel 


\begin{tabular}{|c|c|c|c|c|c|c|}
\hline $\begin{array}{c}\text { Geologic } \\
\text { time }\end{array}$ & \multicolumn{3}{|c|}{ Deformation and structure } & \multicolumn{2}{|c|}{ Metamorphism } & Magmatism \\
\hline \multirow{2}{*}{$\begin{array}{l}\text { Late } \\
\text { Permian ? }\end{array}$} & $D_{5}$ & $\begin{array}{l}\text { NNW-SSE-trending } \\
F_{5} \text { kink folds; local; } \\
\sim \text { E-W compression }\end{array}$ & \multirow{2}{*}{$\begin{array}{l}\text { Final stages of } \\
\text { the late Permian } \\
\text { deformation? or } \\
\text { younger than the } \\
\text { late Permian } \\
\text { deformation? }\end{array}$} & & & \\
\hline & $\mathrm{D}_{4}$ & $\begin{array}{l}\text { NE-SW-trending } F_{4} \\
\text { kink folds; local; } \\
\sim \text { NW-SE compression }\end{array}$ & & & & \\
\hline $\begin{array}{l}\text { Late } \\
\text { Permian }\end{array}$ & $\mathrm{D}_{3}$ & \multicolumn{2}{|c|}{$\begin{array}{l}\text { Tight to isoclinal WNW-ESE-trending } F_{3} \\
\text { folds and high-angle reverse faults; } S_{3} \\
\text { axial plane crenulation cleavage and } \\
\text { disjunctive schistosity; } F_{3} \text { fold axes are } \\
\text { parallel to } F_{1} \text { and } F_{2} \text { axes; tectonic } \\
\text { transport to the SSW; } \sim \text { NNE-SSW } \\
\text { compression }\end{array}$} & \multicolumn{2}{|c|}{$\begin{array}{l}\mathrm{M}_{2} \text { regional metamorphism in the } \\
\text { chlorite zone of the greenschist } \\
\text { facies } \\
\text { (K-Ar biotite cooling age of } 257 \pm 7 \\
\text { Ma in microgranodiorite dike, } \\
\text { Varela et al., 2001) }\end{array}$} & \\
\hline $\begin{array}{c}\text { Early } \\
\text { Ordovician }\end{array}$ & & \multicolumn{2}{|c|}{$\begin{array}{l}\text { Post-orogenic uplift under brittle } \\
\text { conditions (angular enclaves in } \\
\text { microgranodiorite dikes) }\end{array}$} & \multicolumn{2}{|c|}{$\begin{array}{l}\text { Local contact metamorphism in the } \\
\text { country rocks of the } \\
\text { microgranodiorite dikes }\end{array}$} & $\begin{array}{l}\text { Microgranodiorite dikes; Valcheta Pluton, } \\
\text { Ar-Ar muscovite colling ages of } 470 \mathrm{Ma} \text { and } \\
468 \mathrm{Ma} \text { (Gozalvez, 2009; Rapalini et al., } \\
\text { 2013) }\end{array}$ \\
\hline \multirow[t]{2}{*}{$\begin{array}{l}\text { Cambrian } \\
\text { Epoch } 2 \text { to } \\
\text { Early } \\
\text { Ordovician }\end{array}$} & $\mathrm{D}_{2}$ & $\begin{array}{l}\text { Isoclinal and similar WN } \\
F_{2} \text { folds; } F_{2} \text { folds are coe } \\
\text { folds; penetrative } S_{2} \text { axi } \\
\text { WNW-trending } L_{2} \text { lineati } \\
\text { compression }\end{array}$ & $\begin{array}{l}\text { NW-ESE-trending } \\
\text { axial with } \mathrm{F}_{1} \\
\text { ial plane foliation; } \\
\text { ion; NNE-SSW }\end{array}$ & \multirow{2}{*}{$\begin{array}{l}M_{1} \text { regional } \\
\text { metamorphism in } \\
\text { the biotite zone of } \\
\text { the greenchist } \\
\text { facies }\end{array}$} & \multirow{2}{*}{$\begin{array}{l}\text { Slight } \\
\text { increase in } \\
\text { the } \\
\text { metamorphic } \\
\text { conditions of } \\
\text { the } \\
\text { greenschist } \\
\text { facies }\end{array}$} & \\
\hline & $\mathrm{D}_{1}$ & $\begin{array}{l}\text { Isoclinal and similar WN } \\
\mathrm{F}_{1} \text { folds; penetrative } \mathrm{S}_{1} \\
\text { foliation; NNE-SSW co }\end{array}$ & $\begin{array}{l}\text { JW-ESE-trending } \\
\text { axial plane } \\
\text { ompression }\end{array}$ & & & \\
\hline \multirow[t]{2}{*}{$\begin{array}{c}\text { Cambrian } \\
\text { Epoch } 2\end{array}$} & & \multicolumn{4}{|c|}{$\begin{array}{l}\text { Sedimentary protoliths: greywackes, lutites, minor sandstones and granule } \\
\text { conglomerates. } \\
\text { Maximum depositional ages: } 516.6 \mathrm{Ma} \text { to } 515 \mathrm{Ma} \text { from the country rock of the } \\
\text { sills in Aguada Cecilio (unpublished results), } 515 \mathrm{Ma} \text { to } 507 \mathrm{Ma} \text { in the south of } \\
\text { Nahuel Niyeu town (Pankhurst et al., 2006; Rapalini et al., 2013) }\end{array}$} & $\begin{array}{l}\text { Syn-sedimentary magmatism: andesite } \\
\text { lava flow } \\
\text { Magmatism after consolidation of the } \\
\text { clastic sequence }(513.6 \pm 3.3 \mathrm{Ma}) \text { : } \\
\text { gabbro/diorite and peridotite simple sills, } \\
\text { granodiorite-gabbro/diorite and } \\
\text { gabbro/diorite-peridotite composite sills }\end{array}$ \\
\hline & & \multicolumn{5}{|c|}{ Tectonic setting: continental margin basin associated with an active magmatic arc } \\
\hline
\end{tabular}

Fig. 12. Interpretation of the different events in the Nahuel Niyeu Formation of the Aguada Cecilio area (simplified and schematic chart). Not include Permian magmatism.

Niyeu town suggest turbiditic immature deposits with provenance from acidic volcanic and plutonic rocks and (or) metamorphic rocks derived from an active continental margin (Cagnoni et al., 1993; Giacosa, 1997; Caminos, 2001).

According to the lithological, geochemical and geochronological features discussed above, the sedimentary and igneous protoliths of the Nahuel Niyeu Formation could be formed in a continental margin basin associated with an active magmatic arc during the Cambrian Epoch 2 (Fig. 12). A similar setting was earlier suggested by Pankhurst et al. (2006) on the basis of detrital zircon data.

\subsection{Summary of deformation and metamorphism events of the Nahuel Niyeu Formation}

In Fig. 12 we have summarized the main features of the sequence of deformation and metamorphism events and their relationships with the magmatic events in the Aguada Cecilio area.

\subsubsection{Early Paleozoic tectonometamorphic event}

The same metamorphic conditions characterize the development of the NNE-dipping $S_{1}$ and $S_{2}$ foliation planes in both the metasedimentary and metaigneous rocks of the Nahuel Niyeu
Formation (see Section 5.1). The regional metamorphic overprint is estimated to have reached the greenschist facies (biotite zone). Therefore, the coaxial WNW-ESE trending $F_{1}-F_{2}$ folds and their associated $S_{1}$ and $S_{2}$ mineral assemblages would correspond to a main tectonometamorphic event in the biotite zone of the greenchist facies with two progressive phases of deformation $\left(D_{1}-D_{2}-M_{1}\right)$ (Fig. 12). In addition, the greenish brown biotite that defines the $S_{2}$ schistosity in the metamafic rocks and the recrystallization and neoformation of the $S_{1}$ metamorphic assemblage over $S_{2}$ foliation planes in the metasedimentary rocks could indicate a slight increase in the metamorphic conditions of the greenschist facies $M_{1}$ metamorphism from $D_{1}$ to $D_{2}$ deformation phases (Fig. 12).

The timing of the $D_{1}-D_{2}-M_{1}$ tectonometamorphic event is constrained between the emplacement of the pre-kinematic sills and the post- $\mathrm{D}_{2}$ microgranodiorite dikes (Figs. 2 and 3). The post$\mathrm{D}_{2}$ dikes are equivalent to the post-orogenic Punta Sierra Plutonic Complex, regarding their structural relationship with respect to the Nahuel Niyeu Formation. The Valcheta Pluton and equivalent muscovite granite dikes belonging to this complex (Fig. 1b) crosscut the $S_{1}$ and $S_{2}$ foliations of the sills and metasedimentary rocks of the Nahuel Niyeu Formation in the area northwest of Valcheta, according to our observations (Greco et al., 2013, 2014a). Based on 
this relationship, the intrusion of the granite bodies occurred after the $\mathrm{D}_{1}-\mathrm{D}_{2}-\mathrm{M}_{1}$ tectonometamorphic event. Although $\mathrm{U}-\mathrm{Pb}$ crystallization ages are lacking, the $470 \mathrm{Ma}$ and $468 \mathrm{Ma} \mathrm{Ar}-\mathrm{Ar}$ muscovite plateau ages of the Valcheta Pluton (Gozalvez, 2009a; Rapalini et al., 2013) may represent their cooling after crystallization. Therefore, the $D_{1}-D_{2}-M_{1}$ tectonometamorphic event in the Valcheta to Aguada Cecilio area can be constrained between the 513.6 Ma crystallization of the sills and $c a .470$ Ma cooling of the Valcheta Pluton, this means in the Cambrian Epoch 2 to Early Ordovician interval (Greco et al., 2014a) (Fig. 12).

Structural features similar to those detailed above, with $S_{1}$ foliation subparallel to $S_{0}$ bedding planes, are described from the Nahuel Niyeu Formation south of Nahuel Niyeu town (Chernicoff and Caminos, 1996a; von Gosen, 2003). This metamorphic foliation contains aligned sericite + chlorite suggesting lower greenschists facies conditions (von Gosen, 2003). Although a reconstruction of the folding related to the $S_{1}$ foliation and the identification of a $S_{2}$ foliation were not possible in this area, this structure and the associated metamorphism may be equivalent to the $\mathrm{D}_{1}-\mathrm{D}_{2}-\mathrm{M}_{1}$ tectonometamorphic event in Aguada Cecilio area. Moreover, the mineral associations suggest a slight increase in the metamorphic conditions from chlorite grade in Nahuel Niyeu to biotite grade in Aguada Cecilio, as proposed by Caminos and Llambías (1984).

\subsubsection{Late Paleozoic tectonometamorphic event}

The relative age and intrusion conditions of the WNW-ESEtrending microgranodiorite dikes are essential features in order to discriminate the tectonometamorphic events in the Nahuel Niyeu Formation, because the dikes are post- $D_{1}-D_{2}-M_{1}$ and pre$\mathrm{D}_{3}$ intrusions. The strong rheological contrast between the dikes and the low-grade basement rocks, evidenced by angular enclaves and contact metamorphism (Fig. 7b), indicates that the intrusion of the dikes occurred under brittle conditions after the greenschist facies metamorphism associated with the $D_{1}-D_{2}-M_{1}$ event. The brittle conditions may be attained by a regional uplift succeeding the $D_{1}-D_{2}-M_{1}$ event (Fig. 12). Therefore, we consider the $\mathrm{D}_{3}$ structures and associated metamorphism as belonging to a different and younger event than the $D_{1}-D_{2}-M_{1}$ event. The mineral associations that characterize the $S_{3}$ foliation planes in the metasedimentary rocks and $S_{1}$ schistosity in microgranodiorite dikes suggest a low-grade $\mathrm{M}_{2}$ regional metamorphism in chlorite zone of the greenschist facies associated with the $\mathrm{D}_{3}$ structures (Fig. 12).

Regarding to the timing of the $\mathrm{D}_{3}-\mathrm{M}_{2}$ tectonometamorphic event, this should follow the intrusion of the microgranodiorite dikes. Varela et al. (2001) suggested that the dikes belong to the late Paleozoic magmatism on the basis of a $\mathrm{K}-\mathrm{Ar}$ biotite cooling age of $257 \pm 7 \mathrm{Ma}$ (see location of sample AB113 in Fig. 2). In our opinion, however, the dikes are linked to the Early Ordovician magmatism (Fig. 12), whereas the $\mathrm{K}-\mathrm{Ar}$ age to the $\mathrm{D}_{3}-\mathrm{M}_{2}$ tectonometamorphic event. In the case the $\mathrm{M}_{2}$ metamorphism exceeded the closure temperature of biotite in the $\mathrm{K}-\mathrm{Ar}$ system $\left(280 \pm 40{ }^{\circ} \mathrm{C}\right.$, Harrison et al., 1985), the cooling age may be considered close to the $\mathrm{D}_{3}-\mathrm{M}_{2}$ event (Fig. 12). In addition, the SSW-directed tectonic transport caused by $\mathrm{F}_{3}$ folding and reverse faults (Fig. $5 \mathrm{a}$ and $\mathrm{b}$ ) and the probable late Permian age of the $D_{3}-M_{2}$ event are consistent with the late Paleozoic tectonometamorphic and magmatic events in the North Patagonian Massif (Giacosa, 2001; Llambías et al., 2002; Basei et al., 2002; von Gosen, 2002, 2003, 2009). Specifically, von Gosen (2003) described S to SW directed thrusts affecting the Nahuel Niyeu and Sierra Grande formations and the Tardugno Granodiorite, as products of a N-S to NE-SW Permian compression in the south of Nahuel Niyeu (Fig. 1b). Moreover, Chernicoff and Caminos (1996a) reported in this area a folding with tectonic vergence to the SW that refolds the main metamorphic foliation of the Nahuel Niyeu Formation. Therefore, these deformations may be similar to the $\mathrm{D}_{3}$ structures in Aguada Cecilio.

The subparallel $B_{3}$ and $B_{1}-B_{2}$ fold axes permit to interpret the $D_{1}-D_{2}-M_{1}$ and $D_{3}-M_{2}$ tectonometamorphic events as caused by a similar $\sim \mathrm{NNE}-\mathrm{SSW}$ orientation of compression (Figs. 2, 3, 5a, b and 12 ). Therefore, the original orientation of the $F_{1}-F_{2}$ folds, previous to $D_{3}$, should have been similar to the $F_{3}$ orientation. However, we cannot determine the tectonic transport during $\mathrm{F}_{1}-\mathrm{F}_{2}$ folding because the older structures are obscured by the superposition of tight to isoclinal $F_{3}$ folds.

\subsubsection{Final stage of deformation}

$\mathrm{F}_{4}$ and $\mathrm{F}_{5}$ kink folds locally changed the strike and dip of the $\mathrm{D}_{1}$, $D_{2}$ and $D_{3}$ structures (Figs. 2 and 3). However, we cannot determine whether these folds changed the original orientation of the $D_{1}, D_{2}$ and $\mathrm{D}_{3}$ structures within the entire basement of the Aguada Cecilio area. On a regional scale, the $\mathrm{NE}-\mathrm{SW}$ trending $\mathrm{F}_{4}$ folds are parallel and therefore may be equivalent to the NE-SW trending, intense folding between Nahuel Niyeu and Valcheta (Fig. 1b). However, the intensity of folding decreases from NW to SE. These NE-SW trending folds were described by von Gosen (2003), in the south of Nahuel Niyeu, as resulting from a $\sim \mathrm{NW}-\mathrm{SE}$ compression after the $\mathrm{S}$ to $\mathrm{SW}$ directed thrusts discussed in Section 8.2.2. On the other hand, the NNW-SSE-trending $\mathrm{F}_{5}$ folds might be similar to the $\sim \mathrm{N}-\mathrm{S}$ to NW-SE trending fold axes that represent the final stage of the compressive deformational history (under $\sim \mathrm{W}-\mathrm{E}$ compression) in the south of Nahuel Niyeu (von Gosen, 2003).

The final $\sim \mathrm{NW}-\mathrm{SE}$ and $\sim \mathrm{W}-\mathrm{E}$ compressions are not consistent with the $\sim$ NNE-SSW compression established for the late Permian $D_{3}$ deformation. Therefore, the $F_{4}$ and $F_{5}$ folds might belong to the final stages of the Permian deformation as proposed by von Gosen, 2003 or be even younger (Fig. 12).

\subsection{Correlation with other basement units of the northeastern North Patagonian Massif}

The low-grade Nahuel Niyeu Formation has traditionally been compared to the El Jagüelito Formation in the easternmost part of the North Patagonian Massif (Fig. 1c and d; Caminos and Llambías, 1984; Giacosa, 1987; von Gosen, 2003) on the basis of lithology, metamorphic grade and deformation style. Moreover, despite having a higher grade metamorphism dated at $472 \mathrm{Ma}$, the Mina Gonzalito Complex was also compared to the low-grade sequences, on the basis of maximum deposition ages and detrital zircon peak patterns of the siliciclastic protolith (Pankhurst et al., 2006). The protoliths of the marbles, widely distributed in the Mina Gonzalito Complex, were in turn regarded as possible equivalents of the limestone clasts found in a conglomerate layer in El Jagüelito Formation (González et al., 2011b). Further detrital zircon data in these three units (Naipauer et al., 2010; Rapalini et al., 2013; Greco et al., 2014b and unpublished data) agree with the previous idea of similarity in their maximum deposition ages within the Terreneuvian-Cambrian Epoch 2 interval, and Gondwanan provenance patterns of zircon populations.

A comparative summary of the main features of the Nahuel Niyeu Formation, El Jagüelito Formation and Mina Gonzalito Complex is given in Fig. 13 .

The above maximum depositional ages agree with the age provided by the Archeocyath fossils from the El Jagüelito Formation (González et al., 2011b), and the ca. 550-510 Ma deposition age of the marbles from the Mina Gonzalito Complex, derived from a mean ${ }^{87} \mathrm{Sr} /{ }^{86} \mathrm{Sr}$ value of $0.708730 \pm 0.000285$ and compared with the global curve (Varela et al., 2014). Upper limit for deposition of the basement rocks are given by a 513.6 Ma sill of the Nahuel Niyeu 


\begin{tabular}{|c|c|c|c|c|c|c|}
\hline & & & Nahuel Niyeu Formation & EI Jagüelito Formation & Mina Gonzalito Complex & \\
\hline \multirow{2}{*}{ 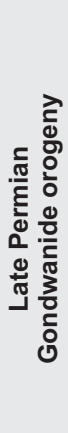 } & \multicolumn{2}{|c|}{ Metamorphism } & $\begin{array}{l}\mathrm{M}_{2}: \text { Regional, low-grade greenschist } \\
\text { facies, chlorite grade } \\
\text { Age: } \sim 260 \mathrm{Ma} \text { (K-Ar date from } \\
\text { dikes,10) }\end{array}$ & $\begin{array}{l}\mathrm{M}_{2} \text { : Local shear zone metamorphism } \\
(5,6,9) \\
\text { Age: } 260 \mathrm{Ma} \text { (Rb-Sr dates from } \\
\text { Ordovician and Permian granitoids, } \\
\text { 15,17) }\end{array}$ & $\begin{array}{l}\mathrm{M}_{2} \text { : Local shear zone metamorphism } \\
\text { (11) } \\
\text { Age: } 260 \mathrm{Ma}(\mathrm{Rb}-\mathrm{Sr} \text { and } \mathrm{Ar}-\mathrm{Ar} \\
\text { dates from the orthogneiss and syn- } \\
\text { orogenic granitoids, 10, 12) }\end{array}$ & $\frac{\pi}{\pi}$ \\
\hline & \multicolumn{2}{|r|}{ Structure } & $\begin{array}{l}\text { Aguada Cecilio area: WNW-ESE- } \\
\text { trending fabric; tectonic transport } \\
\text { to the SSW } \\
\text { South of Nahuel Niyeu town: S to } \\
\text { SW directed thrusts, SW vergent } \\
\text { folds }(7,8)\end{array}$ & $\begin{array}{l}\text { NE-directed thrust and E-W to NW- } \\
\text { SE-trending brittle-ductile shear } \\
\text { zones }(5,6,9)\end{array}$ & El Jagüelito shear zone (11) & 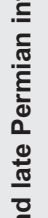 \\
\hline \multirow{3}{*}{ 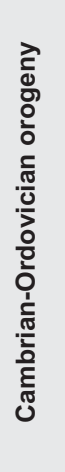 } & \multicolumn{2}{|c|}{ Magmatism } & $\begin{array}{l}\text { Post-orogenic Ordovician } \\
\text { granitoids (Ar-Ar muscovite cooling } \\
\text { ages of } 470 \mathrm{Ma} \text { and } 468 \mathrm{Ma}, 2,9) \\
\text { and microgranodiorite dikes }\end{array}$ & $\begin{array}{l}\text { Post-orogenic Ordovician granitoids } \\
\text { (conventional and SHRIMP U-Pb } \\
\text { zircon ages of } 476-462 \mathrm{Ma})(\mathbf{3}, \mathbf{5}, \mathbf{9}, \\
\mathbf{1 0 , 1 3 , 1 4 , 1 5 , 1 6 )}\end{array}$ & $\begin{array}{l}\text { Syn-orogenic granitoids }(\mathrm{Rb}-\mathrm{Sr} \\
\text { whole rock-mineral isochron age of } \\
452 \mathrm{Ma} 5,10)\end{array}$ & $\frac{\pi}{\frac{\pi}{\pi}}$ \\
\hline & \multicolumn{2}{|c|}{$\begin{array}{c}\text { Regional } \\
\text { metamorphism }\end{array}$} & $\begin{array}{l}\mathrm{M}_{1} \text { : low-grade greenschist facies } \\
\text { (chlorite grade, south of Nahuel } \\
\text { Niyeu, } 4,5,6,7,8) \text {, (biotite grade, } \\
\text { Aguada Cecilio area) } \\
\text { Age: pre-470 Ma }\end{array}$ & $\begin{array}{l}M_{1} \text { : low-grade greenschist facies } \\
\text { (chlorite grade) }(2,3,4,5,6,7,8 \text {, } \\
\text { 9) } \\
\text { Age: pre-476 Ma }\end{array}$ & $\begin{array}{l}\mathrm{M}_{1} \text { : high-grade amphibolite facies } \\
\text { (garnet-sillimanite grade) }(3,4,5) \\
\text { Age: } 472 \mathrm{Ma} \text { (metamorphic growth } \\
\text { rims on detrital zircons, } 6,7)\end{array}$ & 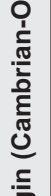 \\
\hline & \multicolumn{2}{|r|}{ Structure } & $\begin{array}{l}\text { Polydeformational WNW-ESE- } \\
\text { trending fabric; tectonic transport } \\
\text { obscured by the superposition of } \\
\text { younger deformation }\end{array}$ & $\begin{array}{l}\text { Simple NNW-SSE to NNE-SSW- } \\
\text { trending fabric; tectonic transport to } \\
\text { the } \sim E(2,3, \mathbf{4}, \mathbf{5}, \mathbf{6}, \mathbf{7}, \mathbf{8}, \mathbf{9})\end{array}$ & $\begin{array}{l}\text { Polydeformational NNW-SSE to NW- } \\
\text { SE-trending fabric; tectonic transport } \\
\text { to the } \sim \operatorname{SW}(3,4,5)\end{array}$ & 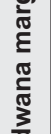 \\
\hline \multirow{2}{*}{ 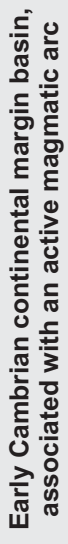 } & \multirow{2}{*}{ 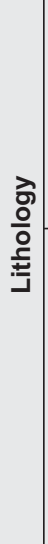 } & 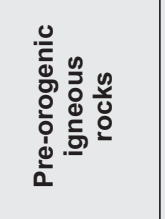 & $\begin{array}{l}\text { Metaandesite lava flow; ultramafic to } \\
\text { felsic (dominantly mafic), simple and } \\
\text { composite sills; tholeiitic magmatism } \\
\text { Age: SHRIMP U-Pb zircon magmatic } \\
\text { crystallization of } 513.6 \mathrm{Ma} \text { (sills) }\end{array}$ & $\begin{array}{l}\text { Metatuffs, metaignimbrites, } \\
\text { metaandedesite and metarhyolite } \\
\text { lava flows, dikes and rhyolite domes; } \\
\text { calc-alkaline magmatism }(\mathbf{8}) \\
\text { Age: Early Cambrian crystallization } \\
\text { ages of metatuffs }(\mathbf{8}, \mathbf{1 2})\end{array}$ & $\begin{array}{l}\text { Amphibolites (tholeiitic magmatism, } \\
\text { 9); Granodiorite Orthogneiss (5) } \\
\text { Age: SHRIMP U-Pb zircon magmatic } \\
\text { crystallization age of } 492 \pm 6 \mathrm{Ma} \\
\text { (orthogneiss, 10) }\end{array}$ & \multirow{2}{*}{ 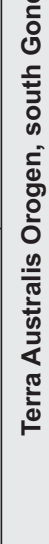 } \\
\hline & & 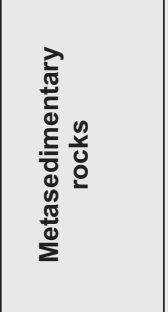 & $\begin{array}{l}\text { Metagreywackes, phyllites, slates, } \\
\text { and minor metasandstones and } \\
\text { granule metaconglomerates } \\
\text { Maximum depositional ages: } 516.6 \\
\text { Ma to } 507 \text { Ma, Gondwanan } \\
\text { provenance (detrital zircons, } \mathbf{1 , 2 , 3 )}\end{array}$ & $\begin{array}{l}\text { Metagreywackes, slates, phyllites, } \\
\text { metasandstones, with minor } \\
\text { metaconglomerates }(\mathbf{1}, \mathbf{2}, \mathbf{3}, \mathbf{4}, \mathbf{5}, \mathbf{6} \text {, } \\
\mathbf{7 , 8 , 9 )} \\
\text { Maximum depositional ages of } 535 \\
\text { Ma and } 523 \text { Ma, Gondwanan } \\
\text { provenance (detrital zircons, } 10,11) \text {, } \\
\text { consistent with Archeocyathan } \\
\text { limestone blocks (7) }\end{array}$ & $\begin{array}{l}\text { Paragneisses, schists and marbles } \\
(\mathbf{1}, \mathbf{2}, \mathbf{3}, \mathbf{4}, \mathbf{5}) \\
\text { Maximum depositional ages of } 540- \\
535 \mathrm{Ma} \text { and } 515 \mathrm{Ma} \text {, Gondwanan } \\
\text { provenance (detrital zircons, } \mathbf{6 , 7} \text { ); } \\
\text { Marbles with deposition ages at 550- } \\
510 \mathrm{Ma}(\mathrm{Sr} \text { isotopes, 8) }\end{array}$ & \\
\hline \multicolumn{7}{|c|}{$\begin{array}{l}\text { Sources: } \\
\text { Nahuel Niyeu Formation: Pankhurst et al., } 2006 \text { (1); Rapalini et al., } 2013 \text { (2); Greco et al. unpublished results (3); Caminos, 1983 (4), 2001(5), } \\
\text { Caminos and Llambías, } 1984 \text { (6);Chernicoff and Caminos, 1996a (7); von Gosen, 2003 (8); Gozalvez, 2009a (9); Varela et al., } 2001 \text { (10). } \\
\text { El Jagüelito Formation: de Alba, } 1964 \text { (1); Giacosa and Paredes, 2001(2); von Gosen, } 2002 \text { (3); González et al., 2002 (4), 2008b (5), 2011a (6), b (7) 2013a (8), b (13), } \\
\text { 2014 (9), unpublished results (12); Pankhurst et al., } 2006 \text { (10); Naipauer et al., } 2010 \text { (11); Varela et al., 1998 (14), 2008 (15), 2009 (17); García et al., 2014a (16). } \\
\text { Mina Gonzalito Complex: Ramos, } 1975 \text { (1); Giacosa, } 1987 \text { (2), 1994a (3), b (4), 2001 (11); González et al., 2008a (5), unpublished data (9); Pankhurst et al., 2006 (6); } \\
\text { Greco et al., 2014b (7); Varela et al., } 2011 \text { (10), } 2014 \text { (8); Grecco and Gregori, } 2011 \text { (12). }\end{array}$} \\
\hline
\end{tabular}

Fig. 13. Simplified and comparative chart of the Nahuel Niyeu and El Jagüelito formations and the Mina Gonzalito Complex. Not include Permian magmatism.

Formation (this contribution), Early Cambrian metatuff intercalated in the El Jagüelito Formation (González et al., 2013a, unpublished data) and a $492 \pm 6$ Ma pre-orogenic granodiorite orthogneiss that intrudes the Mina Gonzalito Complex (González et al., 2008a; Varela et al., 2011). These ages are consistent with the detrital zircon data. With regard to the Yaminué Complex, the only detrital zircon data reported from a paragneiss are interpreted as representing a maximum deposition age in the late Carboniferous (Chernicoff et al., 2013), and its relationship with other associated igneous rocks with early to late Paleozoic ages (Basei et al., 2002; Chernicoff et al., 2013; Rapalini et al., 2013; Pankhurst et al., 2014) are not totally clear.
With reference to the igneous rocks associated with the basement units and involved in their first deformation, the Nahuel Niyeu Formation shows a dominantly mafic magmatism represented by the sills and a lava flow (Fig. 13), while the El Jagüelito Formation has pyroclastic and volcanic rocks such as metatuffs, metaignimbrites, metaandedesite and metarhyolite lava flows, and metarhyolitic dikes and domes (González et al., 2013a). These latter rocks have an arc geochemical signature (calc-alkaline) that suggests proximity of active magmatic arc in the Early Cambrian (González et al., 2013a, unpublished data). This magmatic arc may also be represented by the Early Cambrian Tardugno Granodiorite in the area of Nahuel Niyeu (Rapalini et al., 2013; Pankhurst et al., 
2014). Mafic intrusive rocks intercalated in the El Jagüelito Formation may be comparable to those of the Nahuel Niyeu Formation (González et al., 2008b, 2011a). However, an Ordovician SHRIMP U-Pb zircon age (González et al., 2013a, unpublished data) might invalidate this comparison. Amphibolite layers intercalated parallel to $S_{0}-S_{1}$ planes of the paragneisses and schists of the Mina Gonzalito Complex were interpreted as mafic flows with tholeiitic compositions (Fig. 13; González et al., 2008a and unpublished data). Despite different metamorphic grades, both the Nahuel Niyeu Formation and Mina Gonzalito Complex seem to share similar mafic igneous protoliths. The $492 \mathrm{Ma}$ granodiorite orthogneiss, which intrudes the Mina Gonzalito Complex (Fig. 13; González et al., 2008a; Varela et al., 2011), may represent the position of the magmatic arc subsequent to deposition.

The first, early Paleozoic deformation structure in the El Jagüelito Formation is a simple NNW-SSE-to NNE-SSW-trending fabric with mainly east tectonic transport associated with regional metamorphism in the chlorite zone of the greenschist facies (Fig. 13; Giacosa and Paredes, 2001; von Gosen, 2002; González et al., 2002, 2008b, 2011a, 2014a,b). This $\mathrm{D}_{1}-\mathrm{M}_{1}$ event is pre$476 \mathrm{Ma}$ on the basis of the intrusion of the post-orogenic Punta Sierra Plutonic Complex (Figs. 1d and 13; Varela et al., 1998, 2008; von Gosen, 2002; Pankhurst et al., 2006; González et al., 2008b, 2013b; García et al., 2014a). This situation is equivalent to that of the Nahuel Niyeu Formation, where the first tectonometamorphic event is also constrained by the intrusion of the same plutonic complex (see Section 8.2.1). However, these formations have different structural orientations, which might be explained by internal variation of strain partitioning along the orogen or an effect of younger deformational events which could have changed the original orientation.

The high-grade Mina Gonzalito Complex (Fig. 1c) presents two coaxial, NNW-SSE-to NW-SE-trending folding phases with a $\sim$ SW vergence associated with amphibolite facies regional metamorphism (Fig. 13; Giacosa, 1994a,b; González et al., 2008a) constrained at 472 Ma by metamorphic growth rims on detrital zircons (Fig. 13; Pankhurst et al., 2006; Greco et al., 2014b). These structures are similar to those of the Nahuel Niyeu Formation in Aguada Cecilio area (Fig. 13). The metamorphic climax and associated polyphase deformation are contemporaneous with the intrusion of the post-orogenic Punta Sierra Plutonic Complex. Therefore, the tectonometamorphic event in the high-grade rocks seems to have occurred later than in the low-grade supracrustal rocks (Nahuel Niyeu and El Jagüelito formations). However, these events in the three units might be equivalent, with a time difference typical of regional metamorphism, which is produced by heat conduction in the crust (Stüwe, 2007, p. 362). Rocks from shallow crustal levels or external parts of an orogen, which are under regional metamorphism (e.g. Nahuel Niyeu and El Jagüelito formations), do not heat significantly, reaching greenschist facies conditions. And they are the first to cool when exhumation begins. In contrast, deeper crustal rocks (e.g. Mina Gonzalito Complex) have more time to attain thermal equilibrium, even while exhumation begins, reaching their metamorphic peak later (Stüwe, 2007, p. 362). This may be why the Ordovician magmatism is post-orogenic in the low-grade rocks and syn-orogenic in the high-grade rocks (Fig. 13). Hence, syn-orogenic leucogranites of the Mina Gonzalito Complex (González et al., 2008a) may be equivalent to the post-orogenic Punta Sierra Plutonic Complex. A $\mathrm{Rb}-\mathrm{Sr}$ whole rock-mineral isochron age of $452 \pm 29$ Ma considered as cooling age of a syn-orogenic leucogranite (Fig. 13; Varela et al., 2011) supports this suggestion. The post-orogenic Valcheta Pluton was also correlated with the syn-orogenic granitoids, on the basis of similar geochemical and lithological features (Gozalvez, 2009a).
Late Paleozoic structures related with $\sim \mathrm{NE}-\mathrm{SW}$ compression as in the Nahuel Niyeu Formation (see Section 8.2.2) have been recognized in further areas of the northeastern North Patagonian Massif. The El Jagüelito and Peñas Blancas shear zones (Fig. 1c) are the results of a Permian $\sim$ NE-SW compression (Giacosa, 2001; von Gosen, 2002). They were compared to the S to SW-directed thrusts in the south of Nahuel Niyeu town (see Section 8.2.2; von Gosen, 2002, 2003). In the Sierra Grande-Arroyo Salado area, a NEdirected thrust and $\mathrm{E}-\mathrm{W}$ to NW-SE-trending brittle-ductile shear zones affecting the El Jagüelito Formation were ascribed to the late Paleozoic tectonism by González et al. (2008b, 2011a, 2014a,b) (Fig. 13). In addition, Rb-Sr whole rock-mineral isochron ages of $\sim 260$ Ma from Cambrian granodiorite orthogneiss in the Mina Gonzalito Complex, Ordovician Mina Hiparsa Pluton and Permian Laguna Medina Pluton (Fig. 1c and d) are considered as resetting ages and related to deformation and metamorphism in the Permian (Varela et al., 2008, 2009, 2011). Although $\mathrm{Ar}-\mathrm{Ar}$ biotite and muscovite ages of 264.4 Ma and 261 Ma from the synorogenic leucogranites of the Mina Gonzalito Complex were interpreted as crystallization ages (Grecco and Gregori, 2011), they may also represent resetting ages. Accordingly, the structures and resetting ages described above can be compared with the late Permian tectonometamorphic event $\left(D_{3}-M_{2}\right)$ recorded in the Nahuel Niyeu Formation in Aguada Cecilio area (see Section 8.2.2 and Fig. 13).

From the above discussion, the geodynamic scenario of the northeastern North Patagonian Massif during the Cambrian-Ordovician times can be related to the evolution of the south Gondwana margin. Sedimentary and igneous protoliths of the Nahuel Niyeu and El Jagüelito formations and Mina Gonzalito Complex could be formed in a continental margin basin associated with active magmatic arc (Fig. 13), as suggested earlier by Pankhurst et al. (2006) on the basis of detrital zircon data. This basin was subsequently involved in orogenesis, and therefore, ductilely deformed and regionally metamorphosed (Fig. 13). These processes were accompanied by arc magmatism that lasted up to Middle Ordovician. This scenario is consistent with early Paleozoic sedimentary, tectonometamorphic and magmatic processes that occurred within the Terra Australis Orogen in the south Gondwana margin (Fig. 13; Cawood, 2005). These events are also coeval with the Early-Middle Cambrian stage of the Pampean orogeny and the Late Cambrian-Ordovician part of the Famatinian orogeny of Central Argentina. However, the possibility of the North Patagonian Massif being the southern extension of the Pampean and Famatinian orogens of Sierras Pampeanas region is a matter of further debate (e.g. Pankhurst et al., 2014 and references therein). During late Permian, the basement rocks of the northeastern North Patagonian Massif were again involved in an orogenic process, which is associated with $\sim \mathrm{NE}-\mathrm{SW}$ compression, as also suggested by Giacosa (2001) and von Gosen (2002, 2003). The structures and associated metamorphism related to this compression in the eastern North Patagonian Massif and toward the north in the Chadileuvú Block and the Sierras Australes are consistent and considered as the effects of the Gondwanide Orogeny (von Gosen et al., 1990, 1991, 2002, 2003; Tickyj and Llambías, 1994; Tickyj et al., 1997, 1999; Giacosa, 2001), which is inherent to the late Paleozoic evolution of the Terra Australis Orogen (Fig. 13; Ramos, 2008).

\section{Conclusions}

In summary, we can draw the following conclusions in relation to the magmatic and tectonometamorphic processes during the geologic evolution of the Nahuel Niyeu Formation in the area of Aguada Cecilio: 
1. The metasedimentary sequence of the Nahuel Niyeu Formation contains intercalations of ultramafic to felsic metaigneous rocks which crystallized as a subaqueous lava flow and subvolcanic sills. The lava flow is a metaandesite. The sills are simple or composite and arranged in a swarm. Simple sills are metagabbro/diorites or metaperidotites and predominate over composite sills consisting of metagabbro/ diorites-peridotites or metagranodiorite-gabbro/diorites.

2. The subvolcanic protoliths are spatially, temporarily and genetically connected. A SHRIMP $\mathrm{U}-\mathrm{Pb}$ zircon age of $513.6 \pm 3.3$ Ma obtained from a sill can be assigned to the crystallization age of the entire sill swarm. This age is similar to the maximum depositional ages of the metasedimentary rocks.

3. The sedimentary and igneous protoliths of the Nahuel Niyeu Formation would have been formed in a continental margin basin associated with an active magmatic arc during the Cambrian Epoch 2.

4. The metaigneous and metasedimentary rocks share all deformation structures and the associated metamorphism.

5. The Nahuel Niyeu Formation records two main low-grade tectonometamorphic events. The first event $\left(D_{1}-D_{2}-M_{1}\right)$ is constrained to the Cambrian Epoch 2 to Early Ordovician interval. The second event $\left(D_{3}-M_{2}\right)$ took place probably in the late Permian at $260 \mathrm{Ma}$. Local late folds could belong to the final stages of the Permian deformation or be even younger.

6. From a regional correlation throughout the North Patagonian Massif, the sedimentary and igneous protoliths of the highgrade Mina Gonzalito Complex and the low-grade Nahuel Niyeu and El Jagüelito formations would have been formed in a continental margin basin associated with active magmatic arc during the Early Cambrian. The metamafic rocks of the Mina Gonzalito Complex might be considered as the higher metamorphic equivalents of the metamafic rocks of the Nahuel Niyeu Formation.

7. Despite different metamorphic grades, the Nahuel Niyeu and El Jagüelito formations and the Mina Gonzalito Complex record an equivalent first tectonometamorphic event, which occurred during the early Paleozoic. The Ordovician granitoids are post-orogenic in the low-grade rocks and synorogenic in the high-grade rocks.

8. Cambrian-Ordovician evolution of the basement rocks of the North Patagonian Massif is consistent with the processes that occurred during the early Paleozoic within the Terra Australis Orogen in the south Gondwana margin. This evolution is also coeval with the Early-Middle Cambrian and Late Cambrian-Ordovician stages of the Pampean and Famatinian orogenies of Central Argentina, respectively.

9. The late Permian tectonometamorphic event in the Nahuel Niyeu Formation in Aguada Cecilio area can be compared to the late Paleozoic deformation structures affecting the Mina Gonzalito Complex and El Jagüelito Formation. $\mathrm{Rb}-\mathrm{Sr}$ and $\mathrm{Ar}-\mathrm{Ar}$ resetting ages of $\sim 260 \mathrm{Ma}$ from Cambrian, Ordovician and Permian granitoids may also be compared to this tectonometamorphic event.

10. The late Permian tectonometamorphic event recorded in the Nahuel Niyeu Formation in the area of Aguada Cecilio can be considered as an effect of the Gondwanide Orogeny within the same Terra Australis Orogen.

\section{Acknowledgments}

We wish to express our thanks to Guillermo Cecchi, Ricardo Flores and the people of Valcheta and Aguada Cecilio towns for their kindness and hospitality, and for providing us the permission to access to their properties to perform our field work. We are grateful to W. von Gosen and M. Naipauer for their constructive reviews that helped to improve the present manuscript. Field and laboratory works was supported by the projects UNLP 11/N 653 , PIP-CONICET 0119 and UNRN 40-A-125.

\section{Appendix A. Supplementary material}

Supplementary data related to this article can be found at http:// dx.doi.org/10.1016/j.jsames.2015.04.005.

\section{References}

Aceñolaza, F.G., Miller, H., 1982. Early Paleozoic orogeny in Southern South America. Precambrian Res. 17, 133-146. http://dx.doi.org/10.1016/0301-9268(82)900523.

Aceñolaza, G.F., Toselli, A.J., 1976. Consideraciones estratigráficas y tectónicas sobre el Paleozoico inferior del Noroeste Argentino. In: $2^{\circ}$ Congreso Latinoamericano de Geología. Caracas. Actas, vol. 2, pp. 755-764.

Babcock, L.E., Peng, S., 2007. Cambrian chronostratigraphy: current state and future plans. Palaeogeogr. Palaeoclimatol. Palaeoecol. 254, 62-66. http://dx.doi.org/ 10.1016/j.palaeo.2007.03.011.

Basei, M.A.S., Varela, R., Sato, A.M., Siga Jr., O., Llambías, E.J., 2002. Geocronología sobre rocas del Complejo Yaminué, Macizo Norpatagónico, Río Negro, Argentina. In: Cabaleri, N.G., Cingolani, C.A., et al. (Eds.), XV Congreso Geológico Argentino. El Calafate, Actas, vol. 3, pp. 117-122.

Black, L.P., Kamo, S.L., Allen, C.M., Davis, D.W., Alenikoff, J.N., Valley, J.W., Mundif, R. Campbell, I.H., Korsch, R.J., Williams, I.S., Foudoulis, C., 2004. Improved ${ }^{206} \mathrm{~Pb} /{ }^{238} \mathrm{U}$ microprobe geochronology by the monitoringof trace element related matrix effect; SHRIMP, ID-TIMS,ELA-ICP-MS and oxygen isotope documentation for a seriesof zircon standards. Chem. Geol. 205, 115-140. http:// dx.doi.org/10.1016/j.chemgeo.2004.01.003.

Bucher, K., Grapes, R., 2011. Petrogenesis of Metamorphic Rocks, eighth ed. Springer New York, p. 428

Busteros, A., Giacosa, R., Lema, H., 1998. Hoja 4166-IV, Sierra Grande, Provincia de Río Negro. Servicio Geológico Minero Argentino, Buenos Aires. Boletín 241, 75.

Cagnoni, M., Linares, E., Ostera, H., Parica, C., Remesal, M., 1993. Caracterización geoquímica de los metasedimentos de la Formación Nahuel Niyeu: implicancias sobre su proveniencia y marco tectónico. In: XII Congreso Geológico Argentino y Segundo Congreso Exploración de Hidrocarburos. Buenos Aires. Actas, vol. 1, pp. $281-288$

Caminos, R., 1983. Descripción geológica de las Hojas 39g, Cerro Tapiluke y 39h, Chipauquil, provincia de Río Negro. Servicio Geológico Nacional, Buenos Aires (inédito).

Caminos, R., 2001. Hoja Geológica 4166-I, Valcheta, provincia de Río Negro. Instituto de Geología y Recursos Minerales - Servicio Geológico Minero Argentino, Buenos Aires, p. 73. Boletín 310.

Caminos, R., Llambías, E.J., 1984. El Basamento Cristalino. In: Ramos, V.A. (Ed.), Geología y Recursos Naturales de la Provincia de Río Negro, IX Congreso Geológico Argentino. Buenos Aires, Relatorio, vol. 1, pp. 37-63.

Caminos, R., Chernicoff, C., Varela, R., 1994. Evolución tectónico-metamórfica y edad del Complejo Yaminué, basamento pre-andino norpatagónico, República Argentina. In: $7^{\circ}$ Congreso Geológico Chileno. Concepción. Actas, vol. 2 pp. 1301-1305.

Cawood, P.A., 2005. Terra Australis Orogen: Rodinia breakup and development of the Pacific and Iapetus margins of Gondwana during the Neoproterozoic and Paleozoic. Earth-Sci. Rev. 69, 249-279. http://dx.doi.org/10.1016/ j.earscirev.2004.09.001.

Cawood, P.A., Hawkesworth, C., Dhuime, B., 2012. Detrital zircon record and tectonic setting. Geology 40, 875-878. http://dx.doi.org/10.1130/G32945.1.

Chernicoff, C.J., Caminos, R., 1996a. Estructura y relaciones estratigráficas de la Formación Nahuel Niyeu, Macizo Nordpatagónico oriental, Provincia de Río Negro. Rev. Asoc. Geol. Argent. 51, 201-212.

Chernicoff, C.J., Caminos, R., 1996b. Estructura y metamorfismo del Complejo Yaminué, Macizo Nordpatagónico oriental, provincia de Río Negro. Rev. Asoc. Geol. Argent. 51, 107-118.

Chernicoff, C.J., Zappettini, E.O., Santos, J.O.S., McNaughton, N.J., Belousova, E., 2013. Combined $\mathrm{U}-\mathrm{Pb}$ SHRIMP and Hf isotope study of the Late Paleozoic Yaminue Complex, Río Negro province, Argentina: implications for the origin and evolution of the Patagonia composite terrane. Geosci. Front. 4, 37-56. http:// dx.doi.org/10.1016/j.gsf.2012.06.003.

Compston, W., Williams, I.S., Meyer, C., 1984. U-Pb geochronology of zircons from lunar breccia 73217 using a sensitive high mass-resolution ion microprobe. J. Geophys. Res. 89, 525-534. http://dx.doi.org/10.1029/JB089iS02p0B525.

Cortés, J., 1981. El sustrato precretácico del extremo nordeste de la provincia del Chubut. Rev. Asoc. Geol. Argent. 36, 217-235.

Dalla Salda, L.H., Cingolani, C.A., Varela, R., 1992. Early Paleozoic belt of the Andes in southwestern South America: result of Laurentia-Gondwana collision? Geology 
20, 617-620. http://dx.doi.org/10.1130/0091-7613(1992)020<0617:ЕРОВOT> 2.3. $\mathrm{CO}: 2$

de Alba, E., 1964. Descripción Geológica de la hoja 41j Sierra Grande. Dirección Nacional de Geología y Minería, Buenos Aires, p. 67. Boletín 97.

Evans, B.W., Ghiorso, M.S., 1995. Thermodynamics and petrology of cummingtonite. Am. Mineral. 80, 649-663.

García, V.A., González, S.N., Tassinari, C.C.G., Sato, K., Sato, A.M., González, P.D., Varela, R., 2014a. U/Pb and Nd data from Peñas Blancas Pluton, North Patagonian Massif, Argentina. In: 9th South American Symposium on Isotope Geology. São Paulo. Abstracts, 190.

García, V.A., González, S.N., Tassinari, C.C.G., Sato, K., Sato, A.M., González, P.D., Varela, R., 2014b. Geoquímica y geocronología del Plutón La Verde, Macizo Nordpatagónico, provincia de Río Negro. In: Martino, R.D., et al. (Eds.), XIX Congreso Geológico Argentino. Córdoba, Actas en CD, pp. 373-374.

Giacosa, R., 1987. Caracterización de un sector del basamento metamórfico-migmatítico en el extremo suroriental del Macizo Norpatagónico, Provincia de Río Negro, Argentina. In: X Congreso Geológico Argentino. San Miguel de Tucumán. Actas, vol. 3, pp. 51-54.

Giacosa, R., 1993. El ciclo eruptivo gondwánico en el area de Sierra Pailemán, Macizo Nordpatagónico, Argentina. In: XII Congreso Geológico Argentino y Segundo Congreso de Exploración de hidrocarburos. Buenos Aires. Actas, vol. 4, pp. 113-119.

Giacosa, R., 1994a. Geología y petrología de las rocas pre-Cretácicas del área arroyo Salado-arroyo Tembrao, sector oriental del Macizo Norpatagónico, Río Negro (Ph.D. thesis). Universidad Nacional de la Patagonia San Juan Bosco, Comodoro Rivadavia, p. 200.

Giacosa, R., 1994b. Evolución tectónica pre-Cretácica del margen Atlántico del Macizo Nordpatagónico, Argentina. Zent. Geol. Paläontol. I (7-8), 687-700.

Giacosa, R., 1997. Geología y petrología de las rocas pre-cretácicas de la región de Sierra Pailemán, provincia de Río Negro. Rev. Asoc. Geol. Argent. 52, 65-80.

Giacosa, R., 1999. El basamento pre-silúrico del extremo este del Macizo Nordpatagónico y del Macizo del Deseado. In: Caminos, R. (Ed.), Geología Argentina. Instituto de Geología y Recursos Minerales - SEGEMAR, Buenos Aires, pp. $118-123$.

Giacosa, R., 2001. Zonas de cizalla frágil-dúctil neopaleozoicas en el nordeste de la Patagonia. Rev. Asoc. Geol. Argent. 56, 131-140.

Giacosa, R., Paredes, J., 2001. Estructura de las metamorfitas del Paleozoico temprano en el arroyo Salado. Macizo Norpatagónico, Río Negro. Rev. Asoc. Geol. Argent. 56, 141-149.

Gill, R., 2010. Igneous Rocks and Processes: a Practical Guide. Wiley-Blackwell, Oxford, p. 438.

González, P.D., Poiré, D.G., Varela, R., 2002. Hallazgo de trazas fósiles en la Formación El Jagüelito y su relación con la edad de las metasedimentitas, Macizo Nordpatagónico Oriental, provincial de Río Negro. Rev. Asoc. Geol. Argent. 57, 35-44.

González, P.D., Varela, R., Sato, A.M., Llambías, E.J., González, S., 2008a. Dos fajas estructurales distintas en el Complejo Mina Gonzalito, Río Negro. In: XVI Congreso Geológico Argentino. San Salvador de Jujuy. Actas, vol. 2, pp. $847-848$

González, P.D., Varela, R., Sato, A.M., Campos, H., Greco, G., Naipauer, M. Llambías, E., García, V., 2008b. Metamorfismo regional Ordovícico y estructura de la Ectinita El Jagüelito al SO de Sierra Grande, Río Negro. In: XVII Congreso Geológico Argentino. San Salvador de Jujuy. Actas, vol. 2, pp. 849-850.

González, P.D., Sato, A., Varela, R., Llambías, E., Naipauer, M., Basei, M., Campos, H. Greco, G. 2008c. El Molino Plutón: a granite with regional metamorphism within El Jagüelito Formation, North Patagonian Massif. In: Linares, E. Cabaleri, N.G., Do Campo, M.D., Ducós, E.I., Panarello, H.O. (Eds.), 6th South American Symposium on Isotope Geology. San Carlos de Bariloche. Short Papers, Volume en CD, Paper $\mathrm{N}^{\circ} 41$.

González, P.D., Tortello, M., Damborenea, S., 2010a. Hallazgo de arqueociatos de Cámbrico temprano en Patagonia y su interés paleobiogeográfico. In: X Congreso Argentino de Paleontología y Bioestratigrafía y VII Congreso Latinoamericano de Paleontología. La Plata, Actas en CD, p. 47.

González, P.D., Varela, R., Sato, A.M., Greco, G., Naipauer, M., Llambías, E., 2010b. Evidencias geológicas y paleontológicas en la Formación El Jagüelito para la conexión Patagonia-Antártida durante el Paleozoico inferior. In: X Congreso Argentino de Paleontología y Bioestratigrafía y VII Congreso Latinoamericano de Paleontología. La Plata, Actas en CD, p. 48.

González, P.D., Greco, G. Varela, R., Naipauer, M., Sato, A.M., Llambías, E., García, V., Campos, H., 2011a. Patrón metamórfico invertido en la Formación El Jagüelito de la Herradura del Salado, Basamento Norpatagónico, Río Negro. In: Leanza, H., et al. (Eds.), XVIII Congreso Geológico Argentino. Neuquén, Actas en CD, pp. $85-86$.

González, P.D., Tortello, M.F., Damborenea, S.E., 2011b. Early Cambrian archeocyathan limestone blocks in low-grade meta-conglomerate from El Jaguelito Formation (Sierra Grande, Río Negro, Argentina). Geol. Acta 9, 159-173.

González, P.D., Sato, A.M., Varela, R., Llambías, E.J., Greco, G., González, S.N., García, V., 2011c. Conexión Macizo Norpatagónico - Antártida Oriental: fósiles Arqueociátidos, comparación geológica y circones detríticos. In: Leanza, H. et al. (Eds.), XVIII Congreso Geológico Argentino. Neuquén, Actas en CD, pp. $87-88$

González, P.D., Sato, A.M., Varela, R., Naipauer, M., Llambías, E.J., Castro Dorado, A. 2013a. Volcanismo de arco asociado a la Formación El Jagüelito, Sierra Grande, Río Negro. In: $2^{\circ}$ Simposio Petrología Ígnea y Metalogénesis Asociada. San Luis, Libro de Actas, pp. 39-40.
González, P.D., Varela, R., Naipauer, M., Sato, A., Llambías, E., 2013b. Estratigrafía ígnea del plutón Arroyo Salado, Playas Doradas, Río Negro. In: $2^{\circ}$ Simposio Petrología Ígnea y Metalogénesis Asociada. San Luis, Libro de Actas, pp. 37-38.

González, P.D., Sato, A.M., Varela, R., Greco, G.A., Naipauer, M., Llambías, E.J. Basei, M.A.S., 2014a. Metamorfismo y estructura interna de la Formación El Jagüelito en el Arroyo Salado inferior, Macizo Norpatagónico, Río Negro. In: Martino, R.D., et al. (Eds.), XIX Congreso Geológico Argentino. Córdoba, Actas en CD, pp. 381-382.

González, S.N., Greco, G.A., González, P.D., Sato, A.M., Llambías, E.J., Varela, R., Basei, M.A.S., 2014b. Geología, petrografía y edad U-Pb de un enjambre longitudinal NO-SE de diques del Macizo Nordpatagónico Oriental, Río Negro. Rev. Asoc. Geol. Argent. 71, 174-183.

Gozalvez, M.R., 2009a. Petrografía y edad ${ }^{40} \mathrm{Ar} /{ }^{39} \mathrm{Ar}$ de leucogranitos peraluminosos al oeste de Valcheta. Macizo Nordpatagónico (Río Negro). Rev. Asoc. Geol. Argent. 64, 183-359.

Gozalvez, M.R., 2009b. Caracterización del plutón San Martín y las mineralizaciones de wolframio asociadas, departamento Valcheta, provincia de Río Negro. Rev. Asoc. Geol. Argent. 64, 409-425.

Gradstein, F.M., Ogg, J.G., Schmitz, M.D., Ogg, G.M. (Eds.), 2012. The Geological Time Scale 2012. Elsevier, Amsterdam, p. 1144

Grecco, L.E., Gregori, D.A., 2011. Geoquímica y geocronología del Complejo Plutónico Paileman, Comarca Nordpatagónica, provincia de Río Negro. In: Leanza, H., et al. (Eds.), XVIII Congreso Geológico Argentino. Neuquén, Actas en CD, pp. 91-92.

Grecco, L.E., Gregori, D.A., Rapela, C.W., Pankhurst, R.J., Labudia, C.H., 1994. Peraluminous granites in the northeastern sector of the North Patagonian Massif. In: $7^{\circ}$ Congreso Geológico Chileno. Concepción. Actas, vol. 2, pp. 135-1359.

Greco, G., González, S.N., González, P.D., Sato, A.M., Llambías, E.J., Spacapan, J., 2013. Estructura y metamorfismo de filones capa pre a sinorogénicos en la Formación Nahuel Niyeu, Macizo Norpatagónico oriental. In: $2^{\circ}$ Simposio Petrología Ígnea y Metalogénesis Asociada. San Luis, Libro de Actas, p. 44.

Greco, G.A., González, S.N., González, P.D., Sato, A.M., Llambías, E.J., Tassinari, C.C.G., Basei, M.A.S., Sato, K., Varela, R., 2014a. Cambrian magmatism and CambroOrdovician tectono metamorphic event in Nahuel Niyeu Formation, Northpatagonian Massif, Argentina. In: 9th South American Symposium on Isotope Geology. São Paulo. Abstracts, 168.

Greco, G.A., González, S.N., Sato, A.M., González, P.D., Llambías, E.J., Basei, M.A.S. 2014b. Nueva datación en circones detríticos para el Complejo Mina Gonzalito, Provincia de Río Negro. In: Martino, R.D., et al. (Eds.), XIX Congreso Geológico Argentino. Córdoba, Actas en CD, pp. 1454-1455.

Gregori, D.A., Kostadinoff, J., Strazzere, L., Raniolo, A., 2008. Tectonic significance and consequences of the Gondwanide orogeny in northern Patagonia, Argentina. Gondwana Res. 14, 429-450. http://dx.doi.org/10.1016/ j.gr.2008.04.005.

Harrington, H., 1962. Paleogeographic development of South America. Bull. Am. Assoc. Petrol. Geol. 46, 1773-1814.

Harrison, T.M., Duncan, I., McDougall, I., 1985. Diffusion of ${ }^{40} \mathrm{Ar}$ in biotite: temperature, pressure and compositional effects. Geochim. Cosmochim. Acta 49, 2461-2468. http://dx.doi.org/10.1016/0016-7037(85)90246-7.

Huber-Grünberg, A., 1990. Sedimentologie, Fazies und Herkunft der kambrisch/ ordovizischen und silurisch/unterdevonischen Einheiten von Sierra Grande, Patagonien (Dissertation). University of Munich, p. 196.

Irvine, T.N., Baragar, W.R.A., 1971. A guide to the chemical classification of the common volcanic rocks. Can. J. Earth Sci. 8, 523-548. http://dx.doi.org/10.1139/ e71-055.

Llambías, E., Varela, R., Sato, A.M., 2002. Deformación y metamorfismo neopaleozoico en Yaminué, Macizo Norpatagónico $\left(40^{\circ} 50^{\prime} \mathrm{S}, 67^{\circ} 40^{\prime} \mathrm{O}\right)$ : su relación con la Fase Orogénica San Rafael y el arco de los Gondwánides. In: Cabaleri, N.G., Cingolani, C.A., et al. (Eds.), XV Congreso Geológico Argentino. El Calafate, Actas, vol. 3, pp. 123-128.

López de Luchi, M.G., Wemmer, K., Rapalini, A.E., 2008. The cooling history of the North Patagonian Massif: first results for the granitoids of the Valcheta area, Río Negro, Argentina. In: Linares, E., Cabaleri, N.G., Do Campo, M.D., Ducós, E.I., Panarello, H.O. (Eds.), VI South American Symposium on Isotope Geology. San Carlos de Bariloche. Abstracts, 33.

López de Luchi, M., Rapalini, A.E., Tomezzoli, R.N., 2010. Magnetic fabric and microstructures of Late Paleozoic granitoids from the North Patagonian Massif: evidence of a collision between Patagonia and Gondwana? Tectonophysics 494, 118-137. http://dx.doi.org/10.1016/j.tecto.2010.09.003.

Ludwig, K.R., 2008. User's manual for Isoplot 3.6: a geochronological toolkit for Microsoft Excel. Berkeley Geochronol. Cent. Spec. Publ. 4, 77.

Malvicini, L., Llambías, E., 1974. Geología y génesis del depósito de manganeso Arroyo Verde, provincia del Chubut. In: V Congreso Geológico Argentino. Buenos Aires. Actas, vol. 2, pp. 185-202.

Márquez, M., Massaferro, G., Fernández, M., Menegatti, N., Navarrete, C., 2011. El centro volcánico Sierra Grande: caracterización petrográfica y geoquímica del magmatismo extensional Liásico, noreste de la Patagonia. Rev. Asoc. Geol. Argent. 68, 555-570.

Martínez Dopico, C.I., López De Luchi, M.G., Rapalini, A.E., Kleinhanns, I.C., 2011 Crustal segments in the North Patagonian Massif, Patagonia: an integrated perspective based on Sm-Nd isotope systematics. J. South Am. Earth Sci. 31, 324-341. http://dx.doi.org/10.1016/j.jsames.2010.07.009s.

Martínez, H., Náñez, C., Lizuain, C.D.M., Turel, A., 2001. Hoja Geológica 4166-II, San Antonio Oeste, provincia de Río Negro. Instituto de Geología y Recursos Minerales - Servicio Geológico Minero Argentino, Buenos Aires, p. 32 (Boletín 254). 
McLaren, A.C., Fitz Gerald, J.D., Williams, I.S., 1994. The microstructure of zircon and its influence on the age determination from $\mathrm{Pb} / \mathrm{U}$ isotopic ratios measured by ion microprobe. Geochim. Cosmochim. Acta 58, 993-1005. http://dx.doi.org/ 10.1016/0016-7037(94)90521-5.

Methol, E.J., Sesana, F., 1972. Notas sobre el hallazgo de ortocuarcitas conglomerádicas en la región septentrional del Macizo Norpatagónico. Servicio Nacional Minero Geológico, Buenos Aires (informe inédito).

Middlemost, E.A.K., 1994. Naming materials in the magma/igneous rock system. Earth Sci. Rev. 37 (1), 215-224. http://dx.doi.org/10.1016/0012-8252(94)90029-9.

Naipauer, M., Sato, A.M., González, P.D., Chemale Jr., F., Varela, R., Llambías, E., Greco, G., Dantas, E., 2010. Eopaleozoic Patagonia-East Antartica connection: fossil and $\mathrm{U}-\mathrm{Pb}$ evidence from El Jagüelito Formation. In: 7th South American Symposium on Isotope Geology. Brasilia, pp. 602-605 (Short Paper Volume).

Núñez, E., 1975. Informe preliminar de la Hoja 39 i, Valcheta, provincia de Río Negro. Servicio Geológico Nacional, Buenos Aires (informe inédito).

Núñez, E., Bachmann, E.W. de, Ravazzoli, I., Britos, A., Franchi, M., Lizuaín, A. Sepúlveda, E., 1975. Rasgos geológicos del sector oriental del Macizo Somuncura, provincia de Río Negro, República Argentina. In: $2^{\circ}$ Congreso Iberoamericano de Geología Económica. Buenos Aires, vol. 4, pp. 247-266.

Pankhurst, R.J., Rapela, C.W., Caminos, R., 1993. Problemas geocronológicos de los granitoides gondwánicos de Nahuel Niyeu, Macizo Norpatagónico. In: XII Congreso Geológico Argentino y Segundo Congreso de Exploración de hidrocarburos. Mendoza, Actas, pp. 99-114.

Pankhurst, R.J., Rapela, C.W., 1995. Production of Jurassic rhyolites by anatexis of the lower crust of Patagonia. Earth Planet. Sci. Lett. 134, 23-36. http://dx.doi.org/ 10.1016/0012-821X(95)00103-J.

Pankhurst, R.J., Leat, P.T., Sruoga, P., Rapela, C.W., Márquez, M., Storey, B.C., Riley, T.R., 1998. The Chon Aike province of Patagonia and related rocks in West Antarctica: a silicic large igneous province. J. Volcanol. Geotherm. Res. 81, 113-136. http://dx.doi.org/10.1016/S0377-0273(97)00070-X.

Pankhurst, R.J., Rapela, C.W., Loske, W.P., Fanning, C.M., Márquez, M., 2003. Chronological study of the pre-Permian basement rocks of southern Patagonia. J. South Am. Earth Sci. 16, 27-44. http://dx.doi.org/10.1016/S0895-9811(03) 00017-8.

Pankhurst, R.J., Rapela, C.W., Fanning, C.M., Márquez, M., 2006. Gondwanide continental collision and the origin of Patagonia. Earth Sci. Rev. 76, 235-257. http:// dx.doi.org/10.1016/j.earscirev.2006.02.001.

Pankhurst, R.J., Rapela, C.W., López De Luchi, M.G., Rapalini, A.E., Fanning, C.M., Galindo, C., 2014. The Gondwana connections of northern Patagonia. J. Geol. Soc. 171, 313-328. http://dx.doi.org/10.1144/jgs2013-081.

Peng, S., Babcock, L.E., Cooper, R.A., 2012. The Cambrian Period. In: Gradstein, F., Ogg, J., Schmitz, M., Ogg, G. (Eds.), The Geologic Time Scale, pp. 437-488. http:// dx.doi.org/10.1016/B978-0-444-59425-9.00019-6.

Ramos, V., 1975. Geología del sector oriental del Macizo Norpatagónico entre Aguada Capitán y la Mina Gonzalito, provincia de Río Negro. Rev. Asoc. Geol. Argent. 30, 274-285.

Ramos, V.A., 1984. Patagonia: ¿Un continente paleozoico a la deriva?. In: Congreso Geológico Argentino. Buenos Aires Actas, vol. 2, pp. 311-325.

Ramos, V.A., 2008. Patagonia: a Paleozoic continent adrift? J. South Am. Earth Sci. 26, 235-251. http://dx.doi.org/10.1016/j.jsames.2008.06.002.

Ramos, V., Cortés, J.M., 1984. Estructura e interpretación Tectónica. In: Ramos, V.A. (Ed.), Geología y Recursos Naturales de la provincia de Río Negro. IX Congreso Geológico Argentino. Buenos Aires, Relatorio, vol. 1, pp. 317-346.

Ramos, V., Naipauer, M., 2014. Patagonia: where does it come from? J. Iber. Geol. 40, 367-379. http://dx.doi.org/10.5209/rev_JIGE.2014.v40.n2.45304.

Ramsay, J.G., 1962. Interference patterns produced by the superposition of folds of similar types. J. Geol. 70, 466-481.

Rapalini, A.E., Lopez de Luchi, M., Martínez Dopico, C., Lince Klinger, F., Giménez, M., Martinez, M.P., 2010. Did Patagonia collide against Gondwana in the Late Paleozoic? Some insights from a multidisciplinary study of magmatic units of the North Patagonian Massif. Geol. Acta 8, 349-371.

Rapalini, A.E., López de Luchi, M., Tohver, E., Cawood, P.A., 2013. The South American ancestry of the North Patagonian Massif: geochronological evidence for an autochthonous origin? Terra Nova 25, 337-342. http://dx.doi.org/10.1111/ ter.12043.

Rollinson, H.R., 1993. Using Geochemical Data: Evaluation, Presentation, Interpretation. Longman Scientific, Harlow, p. 352.

Sesana, F.L., 1968. Consideraciones geológicas y petrográficas del plan Valcheta. Dirección Nacional de Geología y Minería, Buenos Aires (informe 464 inédito).

Stacey, J.S., Kramers, J.D., 1975. Approximation of terrestrial lead isotope evolution by a two-stage model. Earth and Planetary Science Letters 26, 207-221. http:// dx.doi.org/10.1016/0012-821X(75)90088-6.
Stüwe, K., 2007. Geodynamics of the Lithosphere, an Introduction, second ed Springer, New York, p. 493.

Sun, S.S., McDonough, W.F., 1989. Chemical and isotopic systematics of ocean basalts: implications for mantle composition and processes. In: Saunders, A.D. Norry, M.J. (Eds.), Magmatism in Ocean Basin, Geological Society of London, Special Publication, vol. 42, pp. 313-345. http://dx.doi.org/10.1144/ GSL.SP.1989.042.01.19.

Tickyj, H., Llambías, E.J., 1994. El gneis milonítico del Cerro de los Viejos $\left(38^{\circ} 28^{\prime} \mathrm{S}-64^{\circ} 26^{\prime} \mathrm{O}\right)$, Provincia de La Pampa, Argentina. "Evidencia de un corrimiento en el Carbonífero inferior". In: $7^{\circ}$ Congreso Geológico Chileno. Concepción. Actas, vol. 2, pp. 1239-1243.

Tickyj, H., Dimieri, L.V., Llambías, E.J., Sato, A.M., 1997. Cerro de Los Viejos $\left(38^{\circ} 28^{\prime} \mathrm{S}-64^{\circ} 26^{\prime} \mathrm{O}\right)$ : Cizallamiento dúctil en el sudeste de La Pampa. Rev. Asoc. Geol. Argent. 52, 311-321.

Tickyj, H., Llambías, E., Sato, A., 1999. El basamento cristalino de la región suroriental de la Provincia de La Pampa: extensión austral del Orógeno Famatiniano de Sierras Pampeanas. In: XIV Congreso Geológico Argentino. Salta. Actas, vol. 1, pp. 160-163.

Tohver, E., Cawood, P.A., Rossello, E., López de Luchi, M.G., Rapalini, A., Jourdan, F., 2008. New SHRIMP $\mathrm{U}-\mathrm{Pb}$ and ${ }^{40} \mathrm{Ar} /{ }^{39} \mathrm{Ar}$ constraints on the crustal stabilization of southern South America, from the margin of the Rio de Plata (Sierra de Ventana) craton to northern Patagonia. In: American Geophysical Union, Fall Meeting. EOS (Abstracts, T23C-2052).

Varela, R., Dalla Salda, L., Cingolani, C., Gómez, V., 1991. Estructura, petrología y geocronología del basamento de la región del Limay, provincias de Río Negro y Neuquén, Argentina. Rev. Geol. Chile 18, 147-163.

Varela, R., Basei, M.A.S., Sato, A.M., Siga Jr., O., Cingolani, C.A., Sato, K., 1998. Edades isotópicas $\mathrm{Rb} / \mathrm{Sr}$ y $\mathrm{U} / \mathrm{Pb}$ en rocas de Mina Gonzalito y Arroyo Salado. Macizo Norpatagónico Atlántico, Río Negro, Argentina. In: X Congreso Latinoamericano de Geología y VI Congreso Nacional de Geología Económica. Buenos Aires, vol. 1, pp. 71-76.

Varela, R., Sato, A.M., Basei, M.A.S., Siga Jr., O., 2001. Edad K/Ar neopaleozoica de filones básicos en la Formación Nahuel Niyeu, Macizo Norpatagónico. Consideraciones Geológicas. In: II Simposio Argentino Paleozoico Superior. Trelew, Resúmenes, p. 30.

Varela, R., Basei, M., González, P., Sato, A., Sato, K., 2008. Granitoides Famatinianos y Gondwánicos en Sierra Grande. Nuevas edades radimétricas método U-Pb. In: XVII Congreso Geológico Argentino. San Salvador de Jujuy. Actas, vol. 2, pp. 914-915.

Varela, R., Sato, K., González, P.D., Sato, A.M., Basei, M.A.S., 2009. Geología y geocronología Rb-Sr de granitoides de Sierra Grande, provincia de Río Negro. Rev. Asoc. Geol. Argent. 64, 275-284.

Varela, R., González, P.D., Basei, M.A.S., Sato, K., Sato, A.M., Naipauer, M., García, V.A. González, S., Greco, G., 2011. Edad del Complejo Mina Gonzalito: revisión y nuevos datos. In: Leanza, H., et al. (Eds.), XVIII Congreso Geológico Argentino. Neuquén, Actas en CD, pp. 127-128.

Varela, R., González, P.D., Philipp, R., Sato, A., González, S., Greco, G., Naipauer, M., 2014. Isótopos de estroncio en calcáreos del noreste patagónico. Resultados preliminares. Rev. Asoc. Geol. Argent. 71, 526-536.

von Gosen, W., 2002. Polyphase structural evolution in the northeastern segment of the North Patagonian Massif (southern Argentina). J. South Am. Earth Sci. 15, 591-623. http://dx.doi.org/10.1016/S0895-9811(02)00111-6.

von Gosen, W., 2003. Thrust tectonics in the North Patagonian Massif (Argentina): implications for a Patagonian plate. Tectonics 22, 1005. http://dx.doi.org/ 10.1029/2001TC901039.

von Gosen, W., 2009. Stages of Late Palaeozoic deformation and intrusive activity in the western part of the North Patagonian Massif (southern Argentina) and their geotectonic implications. Geol. Mag. 146, 48-71. http://dx.doi.org/10.1017/ S0016756808005311.

von Gosen, W., Buggisch, W., Dimieri, L.V., 1990. Structural and metamorphic evolution of the Sierras Australes (Buenos Aires Province/Argentina). Geol. Rundsch. 79, 797-821. http://dx.doi.org/10.1007/BF01879216.

von Gosen, W., Buggisch, W., Krumm, S., 1991. Metamorphism and deformation mechanisms in the Sierras Australes fold and thrust belt (Buenos Aires Province, Argentina). Tectonophysics 185, 335-356. http://dx.doi.org/10.1016/00401951(91)90453-Y.

Williams, I.S., 1998. U-Th-Pb geochronology by ion microprobe. In: McKibben, M.A., Shanks III, W.C., Ridley, W.I. (Eds.), Applications of Microanalytical Techniques to Understanding Mineralising Processes, Reviews in Economic Geology, vol. 7. Society of Economic Geologists, pp. 1-35.

Zanettini, J.C.M., 1981. La Formación Sierra Grande (Provincia de Río Negro). Rev. Asoc. Geol. Argent. 36, 160-179. 